\title{
Examining links between dust deposition and phytoplankton response using ice cores
}

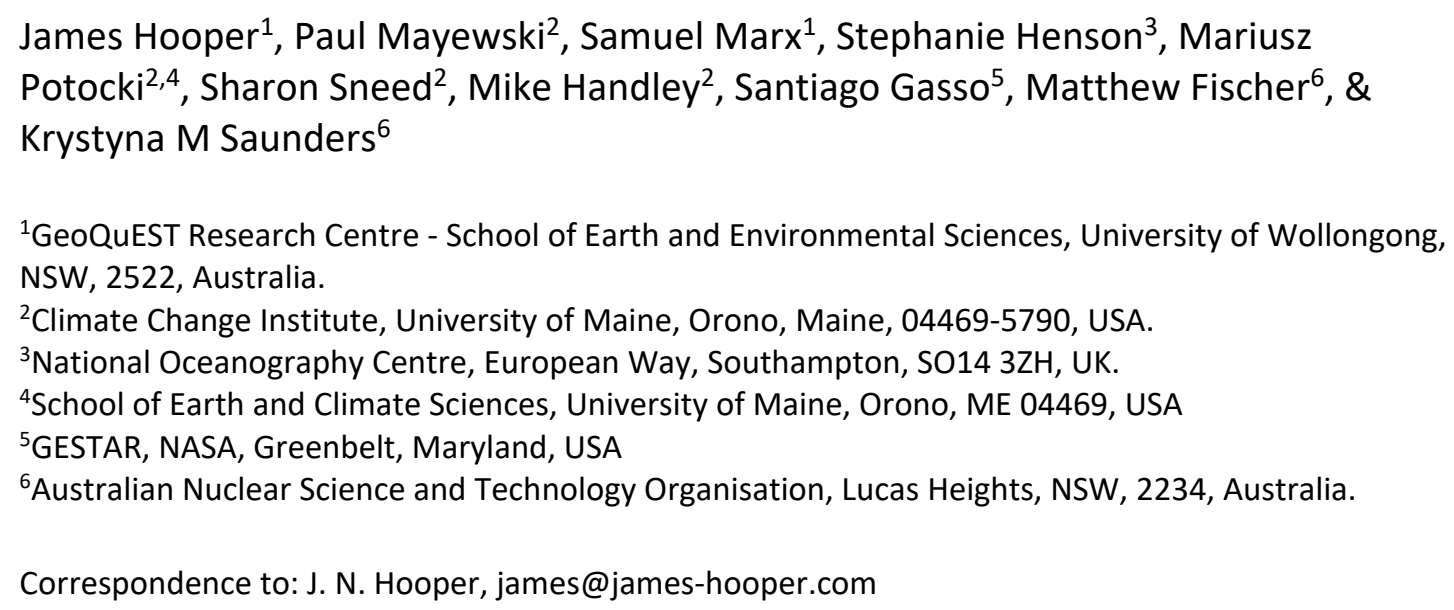

- First study to use contemporary ice core records to explore effect of dust input on primary productivity in High-Nutrient Low-Chlorophyll ocean regions

- Investigates event scale and annual scale correlations between dust-Fe and Methanesulfonic acid in the South Atlantic and North Pacific

- Results suggest that in spatially defined regions, ice cores may provide high resolution records of dust events and primary productivity response

\section{Abstract}

Dust is a major source of nutrients to remote ocean environments, influencing primary productivity (PP). Enhanced oceanic PP causes drawdown of atmospheric $\mathrm{CO}_{2}$ and is considered likely to be a driver of climate variability on glacial-interglacial timeframes. However, the scale of this relationship and its operation over shorter timescales remains uncertain, while it is unclear whether dust fertilisation, or other mechanisms, e.g. nutrient upwelling, are the primary driver of PP in high-nutrient low-chlorophyll (HNLC) ocean regions. In this study, we demonstrate, using dust derived Fe and Methanesulfonic acid (a measure of ocean PP) deposition in ice cores from the South Atlantic (South Georgia Island) and North Pacific (Yukon), that PP is well correlated with Dust-Fe on both an event and annual scale. However, measuring the relationship between (dust) Fe fertilization and PP in high resolution ice cores is subject to a number of highly complex factors, which are discussed and together used to recommend future research directions. In conclusion, our research suggests that changes in aeolian Fe flux, due to climate change and human activity in dust source regions, could have significant implications for HNLC ocean PP and, therefore potentially, carbon sequestration. 


\section{Introduction}

50

51

52

53

54

55

56

57

58

59

60

61

62

63

64

65

66

67

68

69

70

71

72

73

Iron deficiency is a limiting factor for primary productivity (PP) in about one-third of the global ocean (Jickells et al., 2005). In particular, localized artificial Fe fertilization experiments (Boyd et al., 2007) and studies of marine upwelling events (Pollard et al., 2009) have demonstrated Fe deficiency as the primary factor limiting PP in high nutrient, low chlorophyll (HNLC) ocean regions (predominantly high latitude subpolar ocean waters). There remains uncertainty, however, as to the main vectors of Fe supply (as well as other biologically essential trace elements) to the HNLC ocean (Maher et al., 2010), which can include lateral advection of sediments (Chever et al., 2010; Morris and Charette, 2013), aeolian dust, river input, and ocean upwelling and overturning (Serno et al., 2014). As well as being significant for oceanic ecosystems, the relationship between Fe fertilization and oceanic PP is widely considered to influence the carbon cycle by affecting the efficiency of the biological C pump (Blain et al., 2007), although the scale of this effect is understood to vary based on the mode, magnitude and duration of Fe supply (Chever et al., 2010; Le Moigne et al., 2014). In addition to influencing atmospheric $\mathrm{CO}_{2}$ drawdown, phytoplankton may also influence climate through the emission of biogenic sulfur compounds, such as Dimethyl-sulfide (DMS). DMS and its associated oxidation products increase the atmospheric aerosol load, which increases atmospheric albedo directly and also through acting as cloud condensation nuclei (the CLAW hypothesis; Charlson et al., (1987)). DMS therefore represents a key component of the hypothesized negative feedback between increased oceanic PP and atmospheric temperature (Charlson et al., 1987; Martin, 1990). However, sources of $\mathrm{Fe}$, the relationship between fertilization and $\mathrm{CO}_{2}$ drawdown, and the bio-availability of $\mathrm{Fe}$, are all likely to be geographically heterogeneous (Boyd et al., 2010). Some recent studies have suggested upwelling, and lateral advection of sediments from continental shelves, sub-ocean plateaus and island margins (e.g. Chever et al., 2010; Meskhidze et al., 2007; Pollard et al., 2009) as the primary source of Fe controlling biological activity, placing doubt on the importance of dust-Fe in this regard. Other research has suggested that aeolian Fe supply is dominant in parts of the HNLC ocean directly downwind of dry continental areas (Cassar et al., 2007). Therefore understanding the impact of dust derived Fe (as well as other sources of Fe) and the oceanic PP response remains an important goal.

Atmospheric dust deposition is a known source of nutrients to both oceanic and terrestrial environments (Bristow et al., 2010; Jaccard et al., 2013). The mechanism through which aeolian Fe input is expected to influence ocean PP, particularly in HNLC ocean waters (Jickells et al., 2005), was described in the Fe hypothesis (Martin, 1990). In short, by increasing PP and its associated drawdown and potential storage of $\mathrm{CO}_{2}$, dust-Fe fertilisation influences the efficiency of the biological C pump (Falkowski et al., 2000), and is therefore considered to play an important role in the global carbon cycle, which ultimately affects climate (Bristow et al., 2010; Jaccard et al., 2013). Over the glacial/interglacial oscillations of the Quaternary, variability in oceanic dust deposition is considered to have a major influence on atmospheric $\mathrm{CO}_{2}$. For example, it has been proposed that enhanced dust-Fe fertilization (as measured in ice and oceanic sediment cores) accounts for up to $50 \%$ of the glacial/interglacial change in atmospheric $\mathrm{CO}_{2}$ concentrations (Hain et al., 2010; Maher et al., 2010), although a much more 
conservative estimate of $15 \pm 10$ ppm ( 10\%) has been suggested by modelling studies (Kohfeld and Ridgwell, 2009). Despite this, the link between dust fertilization and comparative effects on atmospheric $\mathrm{CO}_{2}$ remains unquantified over shorter timescales.

Dust deposition is estimated to supply $110-320 \mathrm{Kt} / \mathrm{yr}$ of soluble Fe to the ocean, approximately $30 \%$ of which is deposited in HNLC regions, implying dust deposition is an important control on PP in the HNLC ocean (Ito and Shi, 2016; Jickells et al., 2005; Johnson et al., 2010). Evidence for the relationship between dust and PP has been inferred by comparing satellite imagery of continental dust plumes and subsequent levels of oceanic chlorophyll (Chl) along dust transport pathways (Johnson et al., 2011), by investigating the correlation between modeled aeolian deposition and measured net community production throughout the Southern Ocean (Cassar et al., 2007), and by collating frequency of observed dust events upwind with lithogenic mineral and organic carbon flux deposited in ocean sediment traps (Pabortsava et al., 2017; Yuan and Zhang, 2006). However, these studies do not directly measure dust flux, and associated iron input, to the ocean surface. Consequently, there remains uncertainty about the extent of the role of dust in delivering Fe that drives PP in HNLC regions as well as the role of dust vs other nutrient sources, for example, ocean mixing. Overall therefore, the magnitude of the effect of dust on PP remains poorly constrained (Albani et al., 2016).

Empirically quantifying the link between dust input and PP has proven difficult over event (days) to sub-millennial time scales, both in terms of identifying and tracking dust plumes and measuring phytoplankton response. Dust plumes can be spatially and temporally variable, and even large dust plumes can disperse over great spatial areas making their quantification difficult (Marx et al., 2018; McTainsh, 1989). Satellite imagery holds significant potential for measuring dust emissions and oceanic PP, however, while remote sensing has undoubtedly made a major contribution to mapping dust plumes and their effects, the ability to track low concentration dust plumes remains limited (see Marx et al., 2018), i.e. dispersed dust plumes are likely to still be of biogeochemical significance. In addition, and of particular significance for understanding dust and PP links, the use of satellite imagery in the HNLC ocean is significantly limited due to the regular presence of cloud cover in these regions (Bullard et al., 2016; Gassó et al., 2010). As a result, alternative approaches are required to assess the impact of dust on PP.

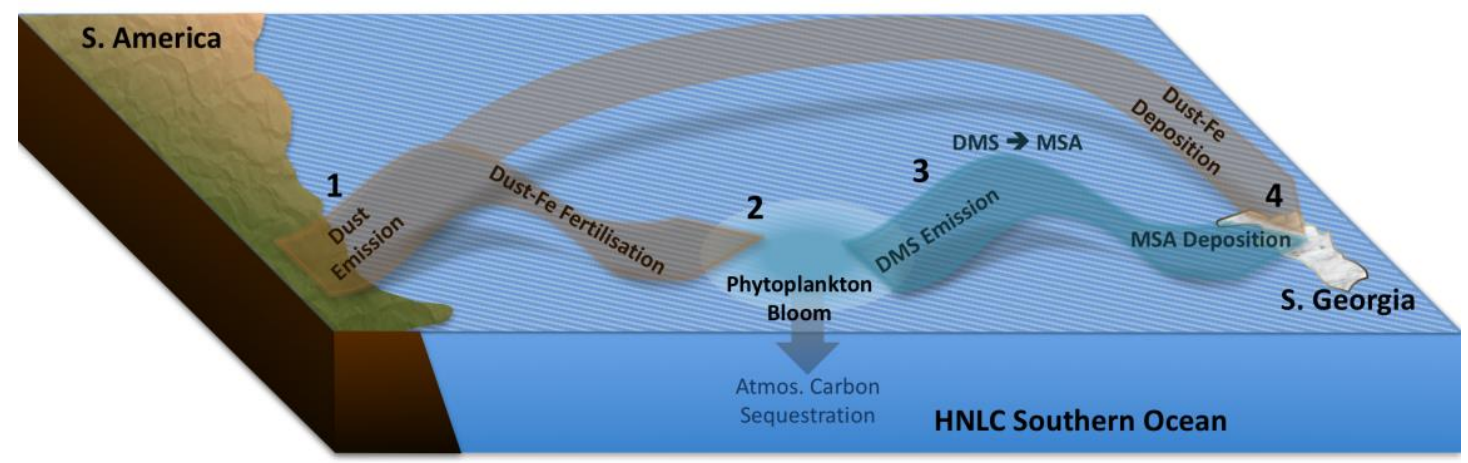

Figure 1. Conceptual diagram illustrating the link between dust deposition, primary productivity (PP) and $\mathrm{CO}_{2}$, and the mechanisms by which temporal variability in this 
relationship is recorded in ice. The South Atlantic Sector of the Southern Ocean is shown in the diagram by way of example. 1) Dust is emitted from a continental source area and transported in the atmosphere. 2) Dust-Fe is deposited in the HNLC ocean resulting in fertilisation and phytoplankton response. 3) Dimethyl-Sulfide (DMS) is emitted from the phytoplankton bloom and oxidised to become MSA. 4) Methanesulfonic acid (MSA) is transported via the same pathways as Dust-Fe and both are deposited through precipitation on a downwind glacier or ice-cap.

Ice cores offer great potential for tracking the relationship between dust and PP. When located downwind of dust sources and HNLC waters, ice cores can record both dust deposition and oceanic PP, via the deposition of Methanesulfonic acid (MSA; Fig. 1), an oxidation product of DMS. DMS is the only atmospheric source of MSA (Legrand et al., 1991; Saltzman et al., 2006), and is emitted to the atmosphere by certain classes of phytoplankton. MSA deposited in Antarctic ice cores has been used to provide an impression of oceanic PP over the glacial-interglacial cycles of the Quaternary, with MSA concentrations typically recording maxima during glacials, although the relationship can be complex (Albani et al., 2016; Johnson et al., 2011; Knudson and Ravelo, 2015). As well as examining MSA over multi-millennial time-scales, ice cores also have potential to examine the links between dust emissions and oceanic PP over much shorter time scales, and in doing so, may provide important knowledge of the short-term response of phytoplankton to dust fertilization.

In this paper we explore the potential relationship between dust derived Fe input and PP in HNLC regions. This is achieved using sub-annual and annual resolution records of Fe and MSA in ice cores downwind of the world's two major HNLC areas, the sub-Arctic North Pacific Ocean (NPO) and South Atlantic sector of the Southern Ocean (SAO) (Johnson et al., 2011; Li et al., 2008). As well as allowing investigation of the dust - PP relationship in these two regions, the two presented cores, from Mount Logan in the Yukon, Canada, and South Georgia Island, allow examination of the effect of dust on oceanic PP over different time scales. Specifically, the South Georgia Core (SGC) allows investigation of event (days) to seasonal scale dust-PP relationships and the Mount Logan Core (MLC) allows investigation of this relationship over annual to centennial time scales. It is expected that these ice cores have the potential to record the response in PP to aeolian-Fe within the HNLC ocean waters between each of the core sites and their respective dust sources (Fig. 2 \& 3).

\section{Methods}

The two regions investigated in this study, the NPO and SAO, are both settings where dust fertilisation may play a significant role in oceanic PP. In addition there are a number of key similarities between the two regions making them appropriate for comparison. Both regions are HNLC ocean areas (Boyd et al., 2007; Maher et al., 2010), downwind of globally significant dust sources, namely South America and East Asia (Ginoux et al., 2012). Both are dominated by large low pressure climatological features; the Aleutian Low is centered over the NPO region (Osterberg et al., 2014), while the high-latitude SAO is influenced by the Antarctic Circumpolar trough (Owens and Zawar-

180 Reza, 2015). Furthermore, existing studies have recorded MSA emissions in both 
regions, demonstrating their suitability for this study. An ice core from Denali National Park in Alaska records MSA deposition that the authors link to PP episodes in the subarctic NE Pacific (Polashenski et al., 2018), while ship-based measurements from the SAO, including upwind of South Georgia, have confirmed MSA as an excellent trace of marine biogenic Sulphur emissions in this region (Zorn et al., 2008).

\subsection{Core locations and likely contributing sources of dust and associated MSA}

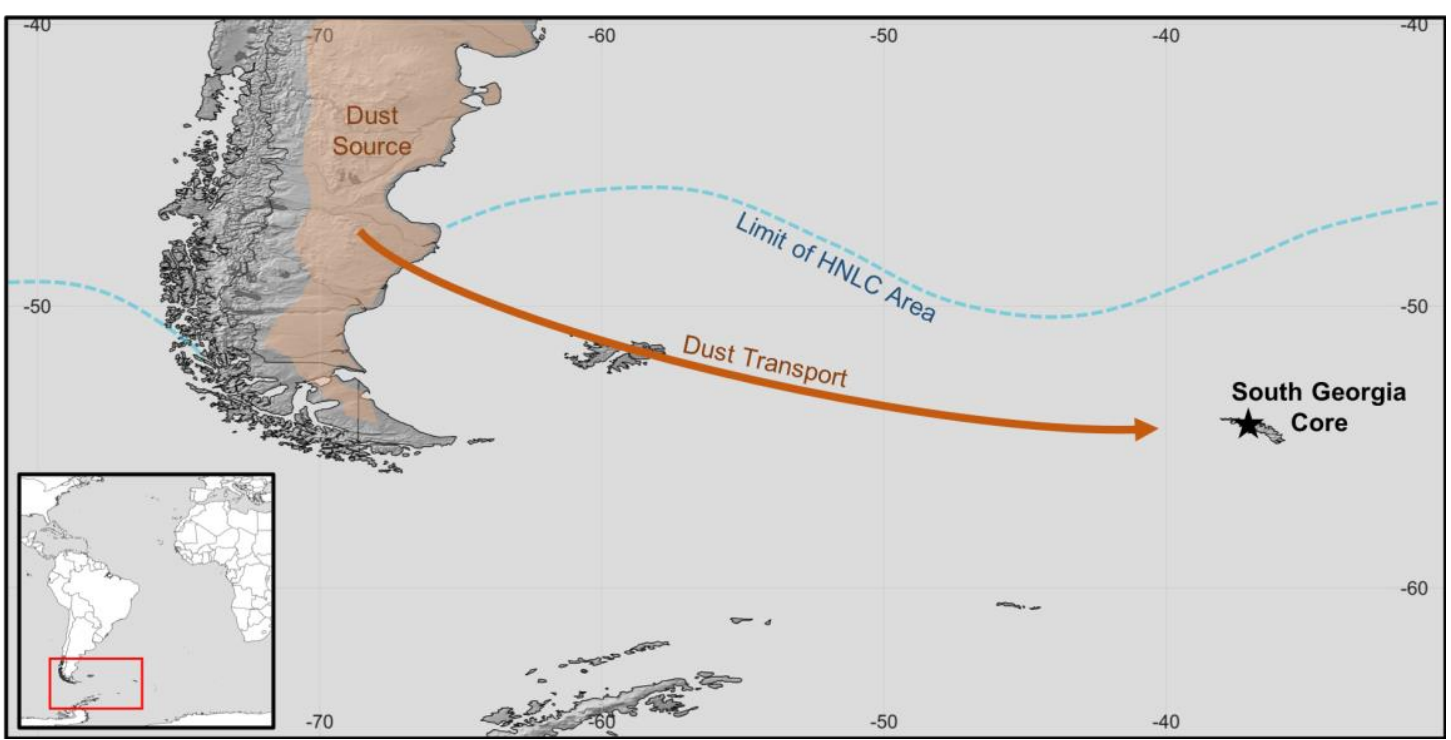

Figure 2. Location of the South Georgia Core (SGC) site (black star) in relation to the major regional dust source area in Patagonia, South America. Dust emissions from Patagonia are transported over the HNLC South Atlantic Ocean by the prevailing westerly winds.

On South Georgia Island, in the South Atlantic, a single $15.39 \mathrm{~m}$ firn core was drilled at the head of the Briggs Glacier (54 191 S, 37 086 W; $950 \mathrm{~m}$ asl) during October 2015 by a team led by the Climate Change Institute at the University of Maine. The core was extracted from an open plateau, which is among the highest altitude areas of the island that can be accessed by ski. The plateau experiences high precipitation, i.e. approximately 2-4 m of snow accumulation per year, and is exposed to prevailing westerly winds. This implies the site has good potential for recording both dust derived from extensive source areas across Patagonia (Prospero et al., 2002) and MSA derived via phytoplankton production in the HNLC region of the South Atlantic Ocean (Fig. 2) (Johnson et al., 2011; Li et al., 2008) (also see Fig. 4). The relatively high altitude of the coring site $(950 \mathrm{~m}$ asl), results in temperatures that are expected to provide amongst the best opportunity to preserve down-core ice integrity in the otherwise relatively mild marine climate of South Georgia (annual temperature range +15 to $-20^{\circ} \mathrm{C}$ at King Edward Point Research Station; 5 m asl). 


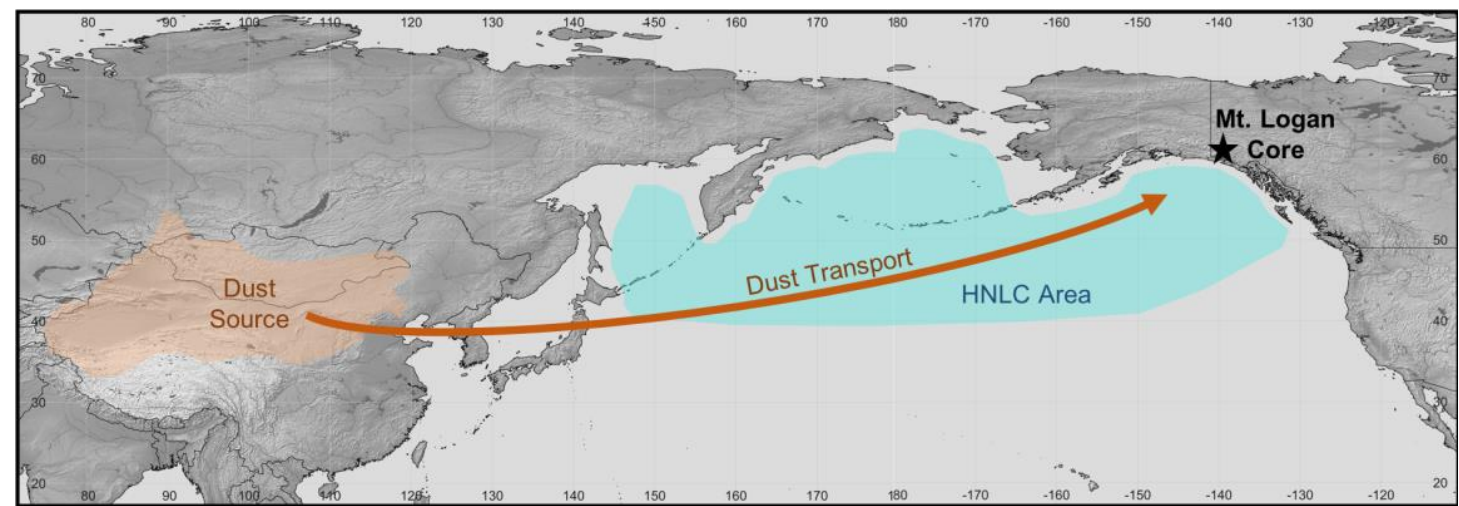

211 Figure 3. Location of the Mount Logan Core (MLC) Site (black star) and the major dust transport trajectory supplying the core site from East Asian dust sources. The HNLC area of North Pacific Ocean stretches from East Asia to North America upwind of the MLC.

At Mt Logan, in the Yukon, Canada, a $186 \mathrm{~m}$ deep ice core was drilled on the summit plateau $\left(60^{\circ} 350 \mathrm{~N}, 140^{\circ} 300 \mathrm{~W} ; 5300 \mathrm{~m}\right.$ asl) during the $2001-2$ summer field seasons. Further details of this core are provided by Osterberg et al., (2008). This location has the potential to record dust from East Asian source areas and associated MSA derived from phytoplankton production in the HNLC region of the North Pacific Ocean (Uematsu, 2003; Yuan and Zhang, 2006; Fig. 3). There is also potential for dust derived from Alaskan fluvial/glacial outwash plains (e.g. Copper River) to contribute to oceanic PP in the Gulf of Alaska (Crusius et al., 2011). Dust from this source is, however, unlikely to be recorded in the Mt Logan core, as satellite derived (CALYPSO) LIDAR suggests Alaskan dust plumes remain below $1000 \mathrm{~m}$ asl (Crusius et al., 2011). This is considered too low to reach the Mt Logan summit plateau, with geochemical fingerprinting implying only East Asian dust reaches high altitudes, while more local (Alaskan sourced dust) is restricted to altitudes below 3000 m (Zdanowicz et al., 2006). Consequently, dust and associated MSA recorded in the Mount Logan ice core are expected to overwhelmingly reflect East Asian dust, with MSA sourced from the central and western North Pacific HNLC ocean waters.

In addition to dust, other sources of Fe have the potential to fertilize phytoplankton production in the HNLC regions of both the North Pacific and the South Atlantic. This includes suspended river sediment, which is likely to contribute to PP in coastal waters, rather than HNLC regions. However, DMS released to the atmosphere from coastal regions of East Asia and Patagonia may contribute to MSA concentrations in the studied cores. In addition, volcanic Fe input may influence MSA concentrations in the longer Mt Logan record. The most significant alternative Fe supply to dust flux comes from ocean mixing, advection of sediments, and upwelling (Pollard et al., 2009). Interestingly, a component of Fe derived from ocean mixing and upwelling may originate from dust input (Sañudo-Wilhelmy and Flegal, 2003), although that hypothesis remains to be fully explored.

\subsection{Core Collection and Sample Analysis}

The South Georgia core (SGC) was retrieved using an electromechanical Stampfli ice coring drill powered by a $12 \mathrm{~V}$ battery, in 29 sections ranging from $11-81 \mathrm{~cm}$ in length. 
Each section was weighed and then split into $10 \mathrm{~cm}$ sub-sections, bounded by ice lenses where possible. The outer layers of each sub-section were shaved using a ceramic knife, while maintaining ultraclean procedures to reduce contamination potential. The cylindrical inner part of each of the 162 core sub-sections was then placed into an acid-washed vial for transport back to the laboratory.

The Mount Logan core (MLC) was collected by the Geological Survey of Canada. It was sampled at a resolution of $1-5 \mathrm{~cm}$ in ultra-clean conditions using an ice core melting system (see Osterberg et al., 2008). While the $186 \mathrm{~m} \mathrm{Mt} \mathrm{Logan} \mathrm{core} \mathrm{record} \mathrm{extended}$ back to 18,400 yrs BP, only the most recent 1000 years of the core, equating to a depth of $\sim 150 \mathrm{~m}$ has an annual resolution. Beyond this age/depth, data have a lower and irregular age resolution. Therefore, only the most recent (1000 - 1998 CE) portion of the record is considered in this study.

Both cores were analysed at the Climate Change Institute at the University of Maine. Major ions $\left(\mathrm{Na}^{+}, \mathrm{K}^{+}, \mathrm{Mg}^{+}, \mathrm{Ca}^{2+}, \mathrm{Cl}^{-}, \mathrm{NO}_{3}{ }^{-}\right.$, and $\left.\mathrm{SO}_{4}{ }^{2-}\right)$ in each sample and $\mathrm{Mt}$. Logan $\mathrm{MS}^{-}$ were analysed on Dionex DX-500 ion chromatographs with suppressed conductivity detection. Cations from both sites were measured using a CS-12A column and MSA eluent. South Georgia major anions were measured using an AS-11 column and $\mathrm{NaOH}$ eluent; the MS ${ }^{-}$was measured separately on a Dionex ICS-2000 ion chromatograph using an AS-11 column and $\mathrm{KOH}$ eluent. Mt. Logan anions (including $\mathrm{MS}^{-}$) were measured using an AS-11 column and $\mathrm{KOH}$ eluent prepared from a Dionex EG-50 eluent generator programed with one gradient change. Inductively coupled plasma mass spectrometry (ICP-MS) was used to measure trace elements (e.g. Pb, Al, Fe, $\mathrm{Sr}, \mathrm{Cs}, \mathrm{U}$, REES) in both cores.

\subsection{Satellite Imagery and Climate Data}

The results from chemical analysis of the high resolution, but temporarily short SGC (see section 3.1) were compared with remote sensing products, air-parcel trajectory analysis and climate data. By comparison, the MLC, which was much longer (1000 1998 CE) but of lower resolution, was not suitable for similar comparisons.

Satellite-derived chlorophyll concentrations and photosynthetically available radiation (PAR) data were obtained from the NASA MODIS-Aqua satellite, (OCX algorithm, reprocessing v2014 was used for chlorophyll data). Data at 8 -day, $9 \mathrm{~km}$ resolution were downloaded from http://oceancolor.gsfc.nasa.gov. Data were spatially averaged in the region upwind of South Georgia identified by back trajectory analysis as being the most likely source region of MSA deposited in the SGC (that is from $51-56^{\circ} \mathrm{S}, 38-48^{\circ} \mathrm{W}$ ). 

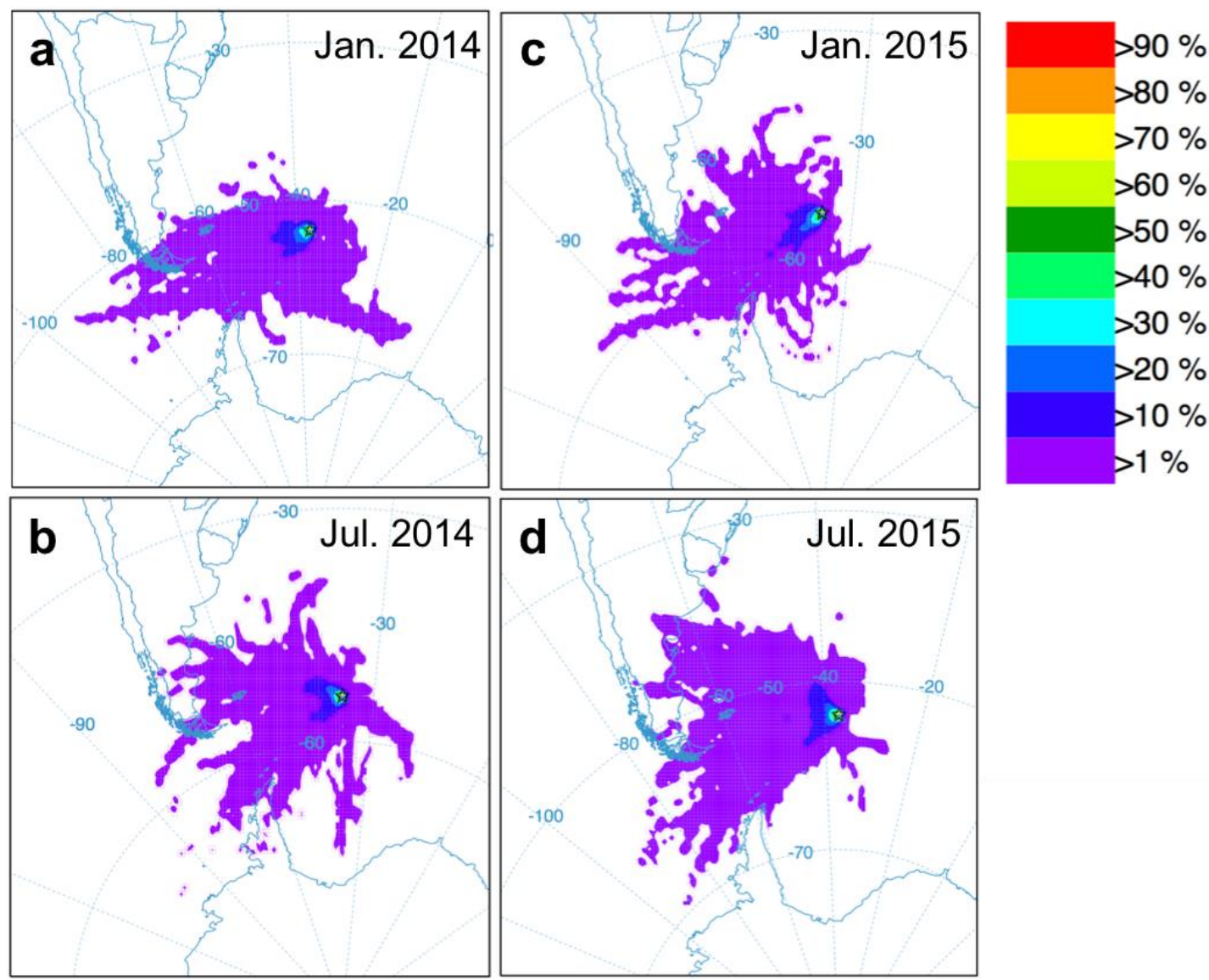

Figure 4. HYSPLIT air mass back-trajectory frequency plots from the South Georgia Core site ( $54^{\circ} \mathrm{S}, 37^{\circ} \mathrm{W}$; at $500 \mathrm{~m}$ above ground level) showing (a) January and (b) July in 2014 and (c) January and (d) July in 2015. The frequency with which air mass back-trajectories were calculated to pass through any given point are denoted by colours presented in the colour key (top right). For example, purple colouring represents an area through which between 1-10\% of all calculated air mass back-trajectories have passed.

Temperature data for King Edward Point (KEP) was retrieved from the British Antarctic Survey and Natural Environment Research Council's data portal website: http://basmet.nerc-bas.ac.uk/. KEP $\left(54^{\circ} 283 \mathrm{~S}, 36^{\circ} 500 \mathrm{~W}\right)$ is a scientific research station located on the central eastern side of South Georgia at the entrance to a small cove within the larger Cumberland Bay. It is protected from the strong westerly winds by the surrounding steep mountains. Data were selected at both hourly and daily mean intervals from $1^{\text {st }}$ January 2012, when the most recent dataset recordings started, until $31^{\text {st }}$ December 2015. This period was assumed to overlap with the studied core. As there were no instrumental precipitation data available for the South Georgia coring site, precipitation data were derived from gridded gauge analysis data, retrieved from the Global Precipitation Climatology Centre (GPCC) 1-degree resolution Version 1 data, for the period $1^{\text {st }}$ January 2012 until $31^{\text {st }}$ December 2015. These data were used to provide an impression of the precipitation variability at the study site. meteorology was selected to generate daily back trajectories for each month up to 3 
years prior to core extraction (total $=36$ months). Back-trajectories were run for 60 hours, starting at 6-hour intervals (Fig. 4). As well as back trajectories, forward trajectories were calculated for an observed dust event on $16^{\text {th }}$ August 2015 . Forward trajectories were started at hourly intervals for 6 hours and run for a 36-hour period from the site of the observed dust event (Fig. 11b).

\subsection{Statistical Analysis}

Statistical analyses were used to assess the degree of match between different data sets and to test for significant temporal change within data. The strength of correlation between different data sets, e.g. dust flux and PP (as indicated by MSA concentrations) were calculated using Pearson's $r$. A spline cross-correlogram was used to investigate the correlation and temporal relationship between MSA in the SGC and remotely sensed ocean $\mathrm{Chl}$ concentrations upwind of South Georgia. This was then used to assess the validity of the age model established for the SGC. Regime shift detection was used to investigate temporal shifts in dust delivery and MSA response in the Mount Logan record. This analysis was not applied to the SGC datasets as that record is too short for such changes to be considered meaningful. Regime shifts were tested using the Sequential Regime Shift Detection analysis (software Ver. 6.2) add in for Excel (Rodionov, 2004). Before applying regime shift detection, the MSA and Fe concentration data were normalised using the natural logarithm after adding one to each value. The residual distributions of fitted models were inspected to check for influential cases. The regime shift detection analysis was performed at a significance level of 0.01 , using a Huber's weight parameter of 2. The selected Huber's weight parameter means that all values less than two standard deviations are weighted equally, which allows capture of $\sim 95 \%$ of data. Cut-off lengths, i.e. the minimum detection length of any statistically significant shift, of 150 and 25 years were selected. The cutoff length of 150 years was selected to investigate long-term variability as recorded in the core, for example as may be associated with the Medieval Warm Period or Little Ice Age, in addition there are likely to be changes in dust flux since the industrial revolution as previously identified (Hooper and Marx, 2018; Osterberg et al., 2008), which may affect PP. A cut-off length of 25 was used to identify any shorter term changes, e.g. as may be associated with changes in the Pacific Decadal Oscillation/North Pacific Decadal Oscillation. All analyses were conducted both with and without OLS red noise estimation, although OLS red noise estimation was not found to alter the outputs.

\section{Results}

\subsection{Dust Deposition}

The location of both ice cores (firn environments high in the landscape) means atmospheric deposition is the only possible source of mineral material to the ice. The concentration(s) of particular trace elements/REEs through the cores that are i) relatively homogenous within upper continental crust, i.e. within terrestrial sediments and ii) behave conservatively during entrainment, transport and deposition/post 
deposition, can be assumed to represent variability in dust deposition (McConnell et al., 2007; Osterberg et al., 2008, Marx et al., 2018). Selected elements that fulfill these criteria, i.e. La and $\mathrm{Ti}$, indicate that both cores record near continuous dust deposition (Fig. 5). Although the high degree of similarity in La and Ti patterns within each core implies that variability in dust flux is the main factor influencing these elements in the ice, there is minor variability between them. These minor differences indicate there is some variability in the specific source area(s) supplying dust to each core through time, that is Patagonia and East Asia have different dust source areas, which are i) distinctive geochemically (Gili et al., 2017; Muhs, 2018) and ii) may emit dust plumes at different times. It is noteworthy that these minor differences in trace element/REE chemistry have been exploited to provenance dust in a number of studies (e.g., Gili et al., 2017; Marx et al., 2009, 2005; Revel-Rolland et al., 2006).

In the SGC there is a regular pattern of dust deposition, with pulses of increased deposition occurring at approximately $1.5 \mathrm{~m}$ intervals through the core (Fig. 5b), most likely representing seasonal variability in dust flux. The resolution of the Mount Logan record precludes seasonal variability. Instead the major observation is an apparent increase in both Ti and La (and therefore dust) after about 1800 CE (Fig. 5a). The MLC also contains a 17-year period between $1565-1581$ CE where no elemental data were

The geographical proximity of Patagonia, a known dust source, to South Georgia, indicates dust in the SGC is almost exclusively derived from this source, as also evidenced by the results of airmass back trajectories computed from the coring site (Fig. 4). Although air-masses originating from the ocean (the South Atlantic, north of South Georgia and the Southern Ocean) and the Antarctic Peninsula may also influence the coring site (Fig.4), these are unlikely to transport dust. Figure 4 also implies there is some seasonal variability in airmass trajectories influencing the study site, with air from further north in Patagonia more frequently influencing South Georgia during the austral winter, while air from the southeast is more likely to influence South Georgia during the austral summer (likely associated with seasonal northward migration of the polar easterlies). The greater frequency of wintertime airmasses from central and northern Patagonia would be expected to result in a higher dust flux to South Georgia, all else being equal, as dust plumes are more frequently emitted from northern Patagonia (Ginoux et al., 2012). Regardless, dust from Patagonia has high potential to deposit nutrients in the South Atlantic and Southern Ocean upwind of South Georgia. 

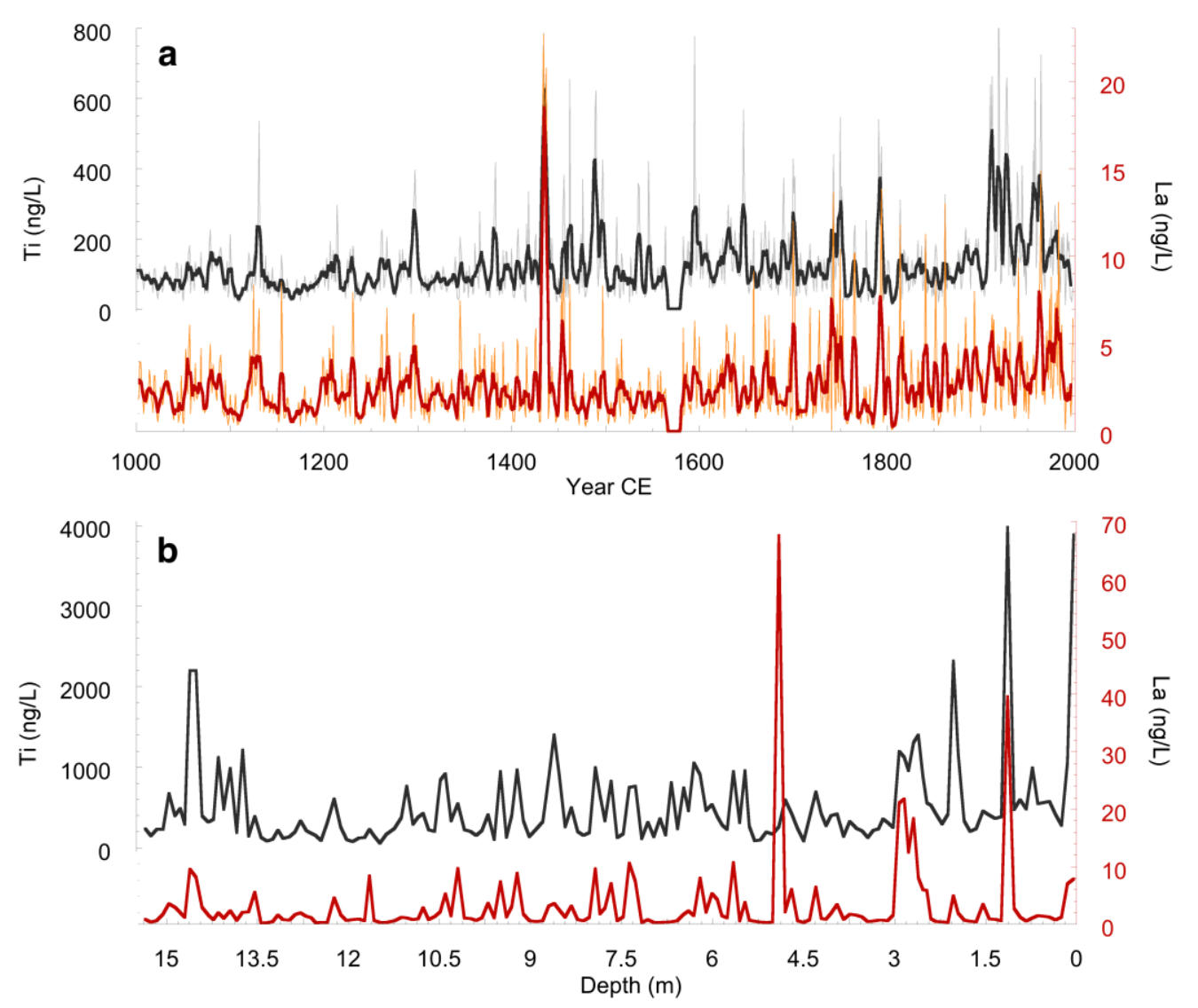

Figure 5. Concentrations of Titanium (Ti) (black line) and REE Lanthanum (La) (red line) in (a) the Mount Logan Core, and (b) The South Georgia Core. Note the bold lines in panel (a) denote a 5-year moving average, while the pale lines are annual average data.

Mount Logan experiences more complex airmass trajectories (plot not shown) by comparison to South Georgia as a result of its more complex topographic position (it is further from the coast and within an extensive alpine region). Despite this, geochemical fingerprinting (using major and trace elements REEs and Pb isotopes) of dust deposited at Mount Logan indicates East Asia is the major source of dust to the summit plateau (Osterberg et al., 2008; Zdanowicz et al., 2006). Similarly to South Georgia, this dust has high potential to fertilize the North Pacific upwind of Mount Logan.

As previously discussed, biologically important trace elements, the most critical of which is Fe, are transported as a component of dust. Iron concentrations in both cores show generally similar patterns to La and $\mathrm{Ti}$ in both cores, although depart from the generalised pattern of La and Ti in some instances (see Fig. 5, by comparison to Figs. 6 and 7). These differences are attributed to variability in Fe concentrations between dust source areas (which is greater than that of the more conservative La and Ti). Consequently, in the SGC, Fe deposition is marked by clusters of peaks within a background of semi-continuous low-level Fe deposition, although still broadly conforming to the seasonal structure displayed by La and Ti (Fig. 5b). 


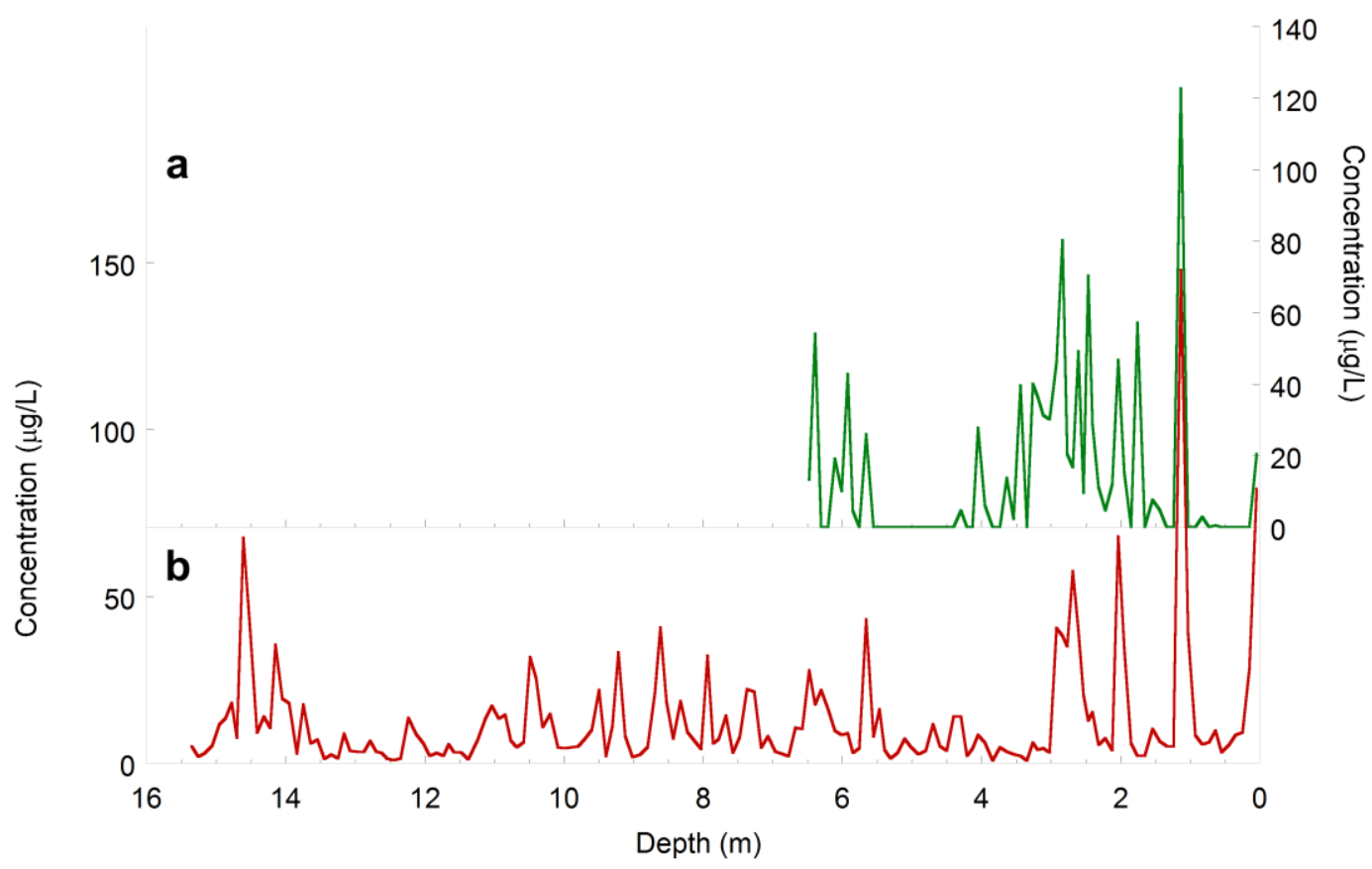

Figure 6. Concentrations of (a) MSA (green) and (b) Fe (brown) in the South Georgia Core. Note, MSA is not detected in the core below a depth of $6.48 \mathrm{~m}$.

In the SGC Fe was present throughout the full $15.39 \mathrm{~m}$ of the core (Fig 6), however, as MSA was only present to a depth of $6.48 \mathrm{~m}$ (see Section 3.2), Fe data are only discussed within this upper portion of the core. Iron concentrations in the upper $6.48 \mathrm{~m}$ of the core averaged $15.5 \mu \mathrm{g} / \mathrm{L}$, however, a number of distinctive spikes were apparent. The most noticeable spike occurred at $1.14 \mathrm{~m}$, where Fe concentrations reached $148 \mu \mathrm{g} / \mathrm{L}$ (Fig. 6). Other significant spikes occurred at 2, 2.5-3, 5.7 and 6.2-6.48 m. These spikes represent significant dust deposition events recorded within the ice.

In the MLC, Fe concentrations averaged $3.78 \mu \mathrm{g} / \mathrm{L}$, with a relatively consistent magnitude and variance throughout most of the past 1000 years, however, there are notable periods of increased Fe deposition, including a major peak between 1433 $1437 \mathrm{CE}$, when average Fe concentrations are approximately double those recorded anywhere else in the core. More significantly, a sustained period of higher Fe concentrations occurs within the $20^{\text {th }}$ Century, matching increased La and $\mathrm{Ti}$ concentrations. Regime shift detection analysis (Rodionov, 2004) was used to assess whether this change was significant and confirmed that a statically significant increase in Fe deposition occurred at either 1874 CE or 1908 CE, using 150-year and 25-year cut off lengths, respectively (Fig. 8a), by comparison to the previous 900 years of the MLC. Similarly, a previous study identified an increase in anthropogenic $\mathrm{Pb}$ and $\mathrm{Al}$ (a proxy for dust) in the MLC from the $18^{\text {th }}$ Century onwards (Osterberg et al., 2008), implying the increase in $\mathrm{Fe}$, Ti and La is also a result of anthropogenic dust (see Hooper and MarX, 2018) . 


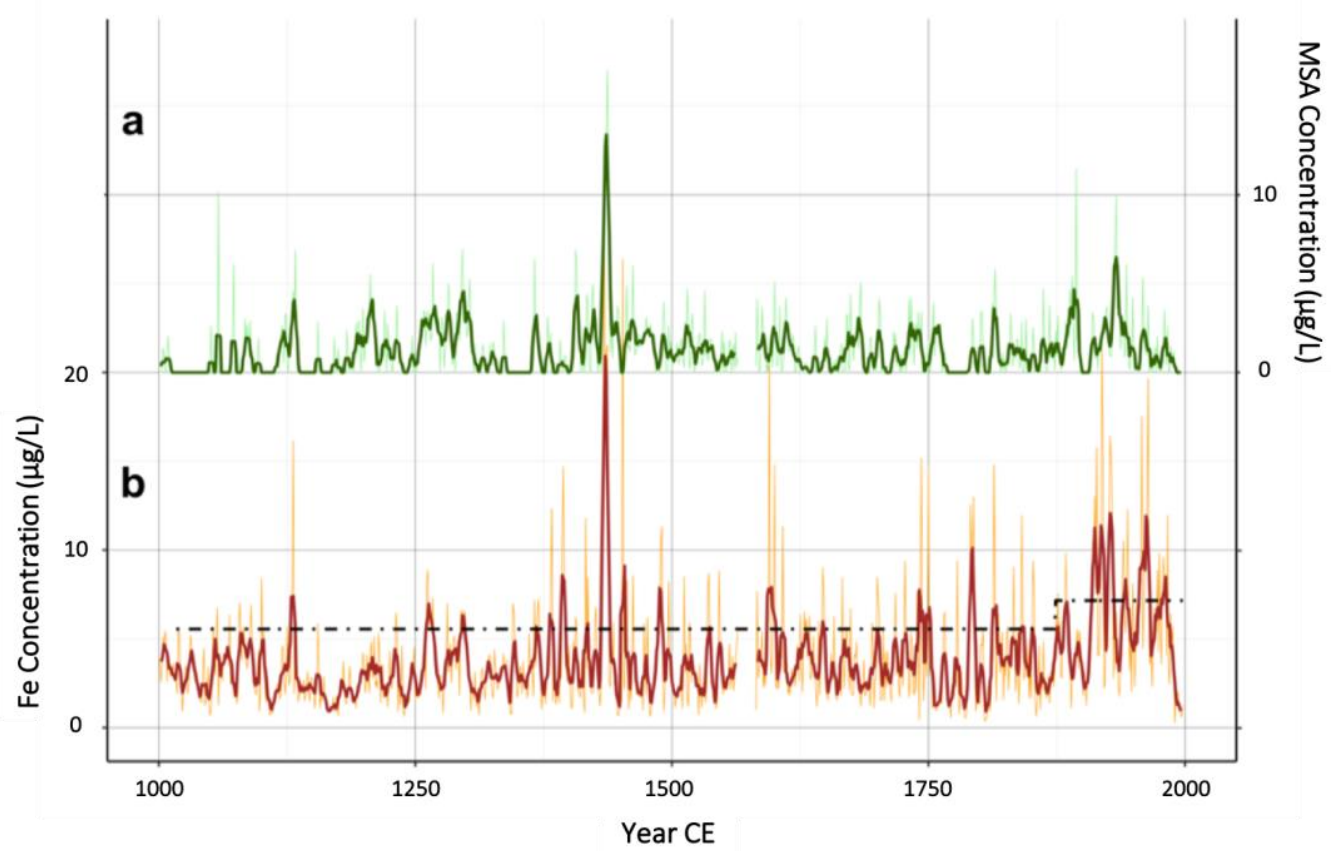

447

Figure 7. MSA and Fe concentrations in the Mount Logan Core. (a) Annual MSA concentrations (light green), and 5-year moving average (dark green). (b) Annual Fe concentrations (light brown), 5-year moving average (dark brown). The black dashed line in panel (b) delineates different regimes in the mean concentration of Fe within the core as determined using Regime Shift Detection (Rodionov, 2004) using a 150 year cut-off length. Note a regime shift occurs at 1874 CE.

\subsection{MSA Concentrations}

Both the SGC and MLC contained a record of MSA deposition. In the SGC average MSA concentrations were $14.72 \mu \mathrm{g} / \mathrm{L}$, with peak concentrations of up to $123 \mu \mathrm{g} / \mathrm{L}$ occurring at $1.14 \mathrm{~m}$ depth (Fig. 6). Although MSA was present in the top of the core, it was not detected after $6.48 \mathrm{~m}$ depth (Fig. 6). Similarly, other soluble elements (e.g. Ca, Na and $\mathrm{K}$; data not shown) were also not present beyond $6.48 \mathrm{~m}$ depth. The mostly likely reason for the disappearance of MSA beyond $6.48 \mathrm{~m}$ is that the core experienced a period of melt which resulted in the wash out of MSA (and other soluble elements) from this lower section of the core (also see Section 3.3.1).

MSA concentrations in the upper $6.48 \mathrm{~m}$ of the SGC show two distinct regions of higher concentration between 1 and $4.5 \mathrm{~m}$ depth, and between 5.5 and $6.48 \mathrm{~m}$ depth (Fig. 6). This pattern is similar to that displayed by both $\mathrm{Fe}$, and to a greater extent, La and $\mathrm{Ti}$, and again likely reflects seasonal variability in MSA deposition. 

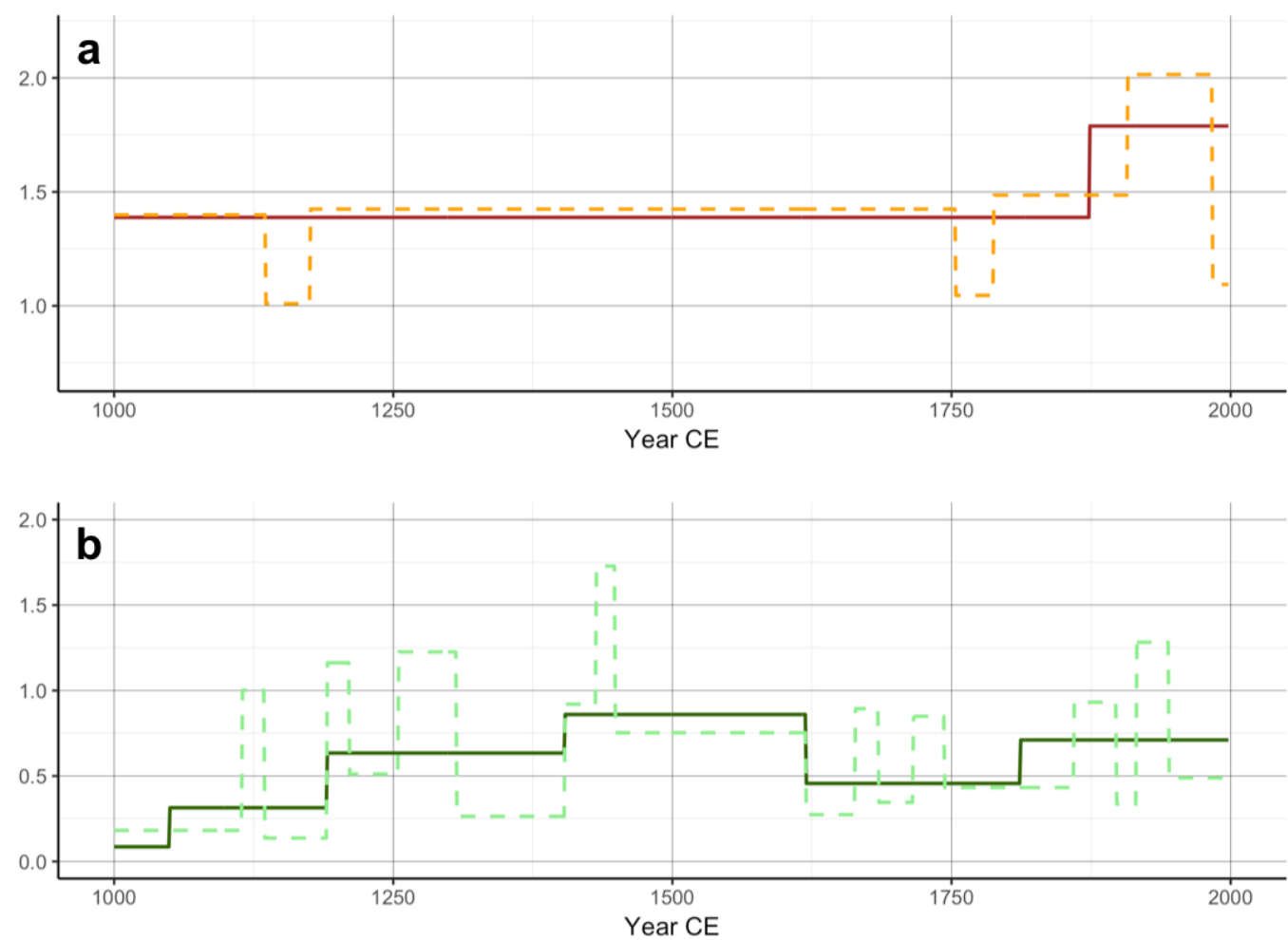

Figure 8. Regime Shift detection analysis of Fe and MSA concentrations within the Mount Logan core. (a) Mean log-normalised Fe values, analysed using a 25-year (lightbrown dashed line) and a 150-year length cut off (dark-brown solid line). (b) Mean lognormalised MSA values, analysed using a 25-year (light-green dashed line) and 150year cut off lengths (dark-green solid line).

In the MLC, MSA was detectable semi-continuously through the core. The highest recorded concentrations were $17 \mu \mathrm{g} / \mathrm{L}$, while mean concentrations were $1.2 \mu \mathrm{g} / \mathrm{L}$. It is noteworthy that these are an order of magnitude lower than that recorded in the SGC (Fig. 7), likely reflecting the longer and more complex transport pathway of MSA to Mount Logan. Within the MLC record, there are a number of periods where MSA was not detectable (Fig. 7). These could either represent periods when MSA concentrations are below detection limits, or they could reflect post deposition loss, such as washout of MSA by water movement through the core. However, in all but one case, soluble elements such as $\mathrm{Ca}$, that would also be expected to be affected by water movement in the core, do not exhibit any apparent washout implying MSA concentrations are below detection limits in the majority of cases. The one exception occurs between 1565 - $1581 \mathrm{CE}$, when Fe, Ca, MSA and even dust (as indicated by La and Ti) are not recorded in the core, suggesting a major perturbation (such as melting) event occurred in that section of the core.

Similar to Fe concentration data, MSA in the MLC appears to show little obvious change in magnitude or variance over the thousand-year record. Again similar to Fe, MSA also displays prominent maxima between 1433 - 1437 CE (Fig. 7a). In contrast to Fe, however, regime shift detection analysis performed on the MSA data showed 
numerous regime shifts in MSA concentrations at both 25-year $(n=18)$ and 150-year

$500(n=6)$ cut off lengths (Fig. 8b). A sustained peak in MSA concentrations appears to have 501 occurred between $1404 \mathrm{CE}$ and $1619 \mathrm{CE}$, while more recently mean MSA 502 concentrations showed an increase from 1812 CE until the top of the core by 503 comparison to the period between 1625 and $1750 \mathrm{CE}$.

\subsection{Core Chronology}

\subsubsection{South Georgia Core Chronology}

It was not possible to date the SGC using conventional isotopic techniques due to the high firn accumulation rate $(\sim 3 \mathrm{~m} / \mathrm{yr})$ combined with the shallow depth $(15.39 \mathrm{~m})$ of the core. Instead a chronology was developed for the core based on; 1) matching patterns in core MSA with remotely sensed ocean chlorophyll (Chl) concentrations; 2) application of a spline cross-correlogram to statistically test this relationship; 3 ) constraining the date of the MSA burnout (below $6.48 \mathrm{~m}$ depth) using air temperature data; and 4) comparing estimated annual precipitation with the snow water equivalent (w.e.) in the core. These approaches are discussed in brief here, with a more detailed discussion in the Supplementary material.

As previously discussed, MSA data in the SGC shows an apparent seasonal signal. Satellite derived ocean Chl data from upwind of South Georgia also have a pronounced seasonal pattern (Fig. 9c). Therefore matching the MSA pattern from the SGC with the seasonal cycle in Chl provides an approximation of the chronology for the upper 6.48 $\mathrm{m}$ of the ice core. Aligning the date the core was extracted $\left(17^{\text {th }}\right.$ October 2015$)$ with the remotely sensed $\mathrm{Chl}$ data, implies the lower end of enhanced MSA period dates from the austral summer/autumn 2014. Consequently, the core is expected to represent approximately a $20-25$ month period, that is, $6.48 \mathrm{~m}$ depth in the SGC equates to a date between November 2013 and April 2014.

The validity of using MSA and Chl data to establish a chronology for the core was further examined by using a red-noise tested spline cross-correlogram to test the relationship between the MSA concentrations in the SGC and oceanic Chl (Bjørnstad and Falck 2001). The result of this analysis demonstrates a significant correlation occurs between MSA and Chl (Fig. 10), with the highest correlation (0.33, p<0.001) occurring with a lag of +16 days (a similar correlation occurs with no lag however; $0.32, p<0.001$ ). Results also show the strong seasonal control on the relationship, with significant negative correlations at 180-200 days. The significance of the correlation was evaluated further using a red noise null hypothesis test to calculate 95\% confidence intervals for the spline cross-correlogram (see Supplementary material), confirming the significance of the correlation between the SGC MSA concentrations and oceanic Chl, and supporting the use of these data to construct a chronology for the core based on their temporal relationship.

A potentially more precise age estimate of the base of the SGC can be provided by matching the depth at which MSA disappears to the climate conditions likely to be responsible for the loss of MSA at $6.48 \mathrm{~m}$ depth. While a variety of factors can lead to 
546 MSA mobility in ice cores (Osman et al., 2017), the movement of liquid water is the 547 most likely cause of MSA loss in this case (Moore et al., 2005; Supplementary material). 548 The presence of liquid water in the snow pack is most likely during snow pack melt 549 during warm temperatures. Temperature records from South Georgia show the 550 warmest conditions between January 2012 and December 2015 occurred on the $17^{\text {th }}$ 551 and $19^{\text {th }}$ February 2014 at $13.6^{\circ} \mathrm{C}$ and $14.2^{\circ} \mathrm{C}$, respectively (Fig. 9e), with temperatures 552 above $10{ }^{\circ} \mathrm{C}$ throughout this period. These conditions are likely to have resulted in snow 553 pack melt and subsequent washout of MSA. Importantly these dates are within the 554 date range estimated for the core at $6.48 \mathrm{~m}$ depth (i.e., November 2013 to April 2014) based on the ChI/MSA association.

A third estimate of the age of the core can be provided by the likely snow/ice 558 accumulation rate at the coring site. Precipitation at the site is likely to approximate $559180 \mathrm{~mm} / \mathrm{month}$ (See Supplementary material), equating to $3950 \mathrm{~mm}$ w.e. for the 560 period between $19^{\text {th }}$ February 2014 and $12^{\text {th }}$ October 2015 . By comparison, the upper $5616.48 \mathrm{~m}$ of the SGC has $3026 \mathrm{~mm}$ w.e. accumulation, broadly comparable to estimated 562 precipitation rates (taking into account some post depositional loss of snow, due to 563 strong winds at the exposed SGC site). Overall therefore, the precipitation data broadly 564 agree with ages for the core suggested by both the Chl / MSA data and the timing of 565 the loss of MSA beyond $6.48 \mathrm{~m}$ depth. 


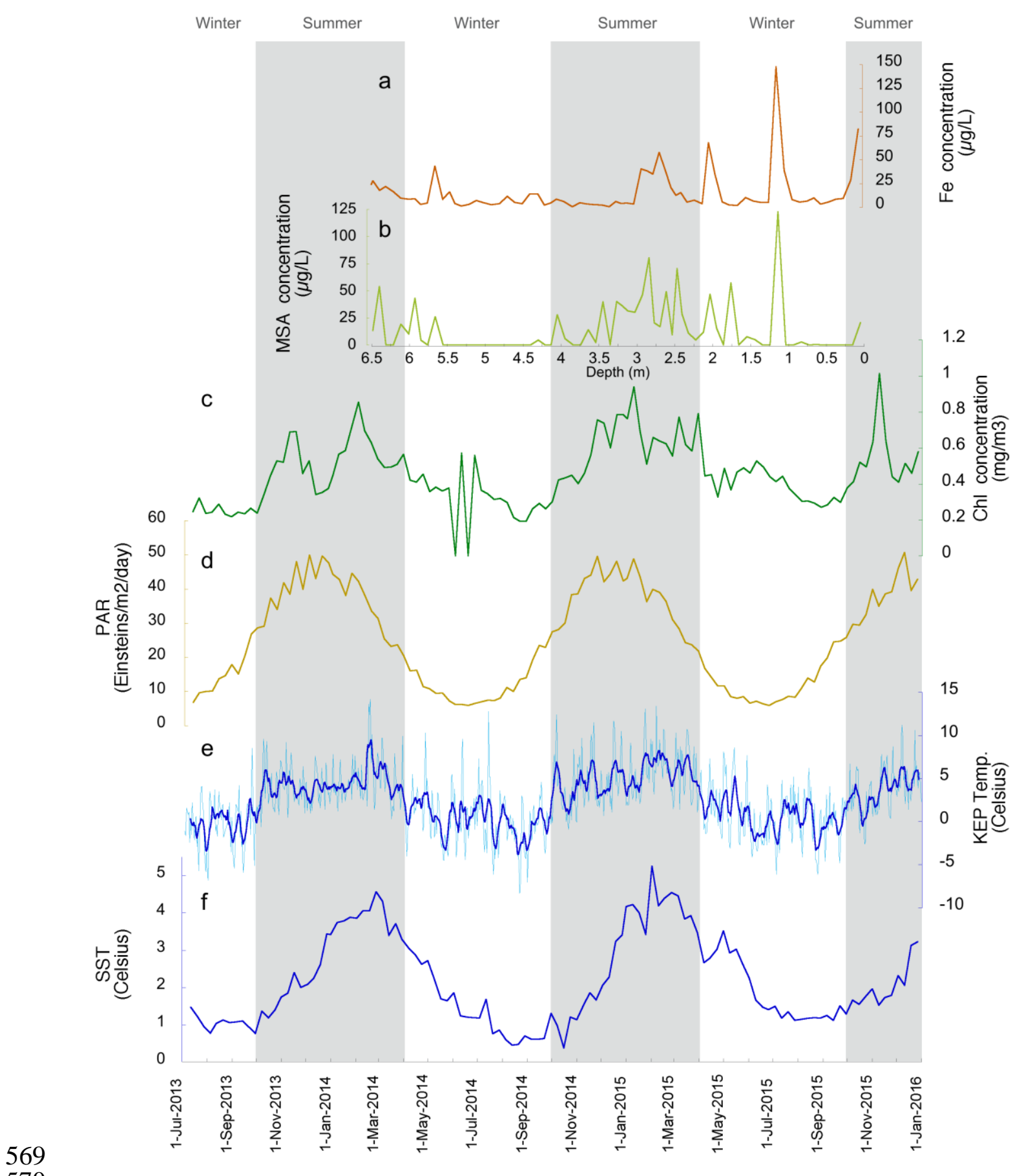

Figure 9. (a) Fe concentrations and (b) MSA concentrations in the South Georgia Core. Zero depth equates to $17^{\text {th }}$ October 2015, the date the core was collected. (c) Average remotely-sensed chlorophyll (Chl) concentrations and (d) Average remotely-sensed Photosynthetically Available Radiation (PAR) in the area $51-56^{\circ} \mathrm{S}, 38-48^{\circ} \mathrm{W}$ upwind of South Georgia. (e) South Georgia, King Edward Point station (KEP) mean daily temperature (light blue), smoothed with an 8-day moving average (dark blue). (f) Average remotely-sensed Sea Surface Temperature (SST) in the area $51-56^{\circ} \mathrm{S}, 38-48^{\circ} \mathrm{W}$ upwind of South Georgia. 


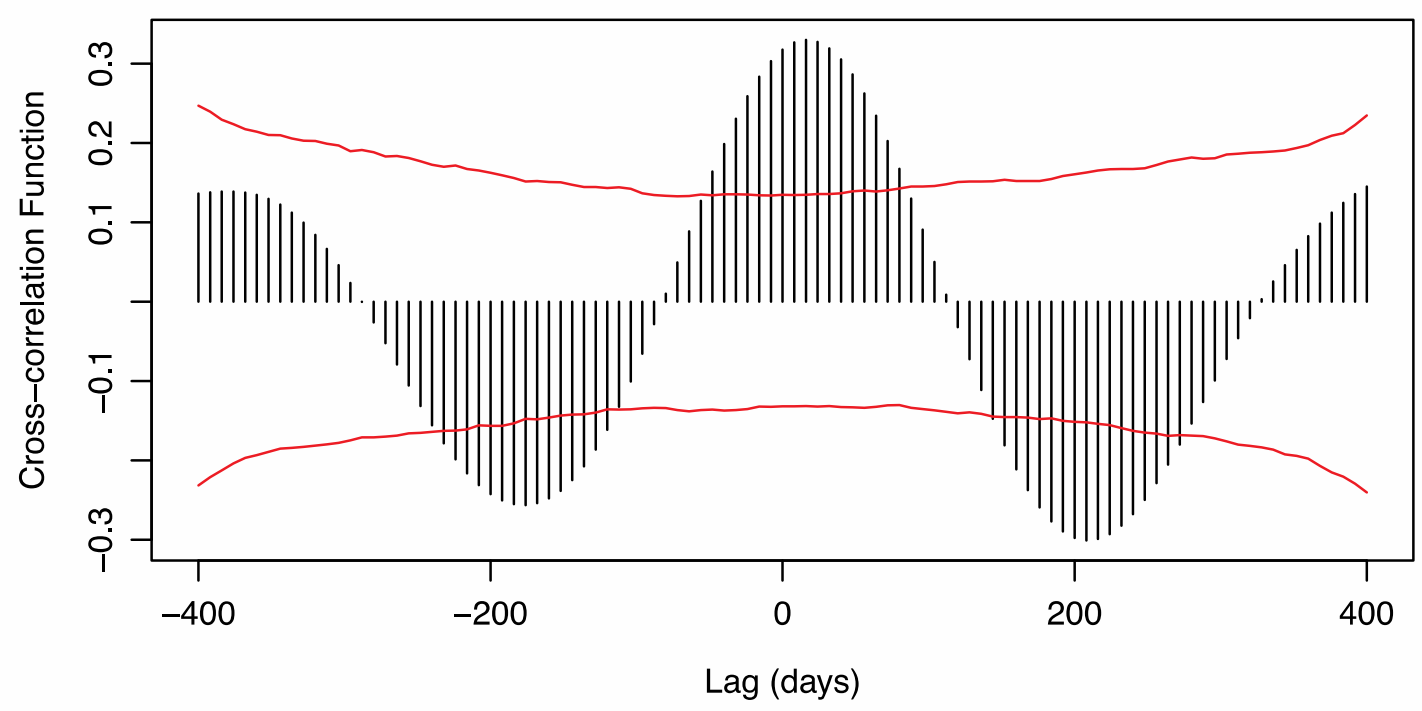

582

Figure 10. Results of a spline cross-correlogram between MSA from the South Georgia core and remotely $\mathrm{Chl}$ data from 51-56 $\mathrm{S}, 38-48^{\circ} \mathrm{W}$ for the period $18^{\text {th }}$ February 2014 and $17^{\text {th }}$ October 2015. The red lines indicate the 95\% confidence intervals of the red noise null hypothesis test.

\subsubsection{Mount Logan Core Chronology}

The upper section of the Mt. Logan Core (MLC) provides a 1000-year annually resolved deposition record ending in $1998 \mathrm{CE}$, with a snow accumulation rate of $0.41 \mathrm{~m} / \mathrm{yr}$ (w.e.) (Osterberg et al., 2014, 2008). The Mount Logan core chronology was established by annual layer counting of seasonal oscillations in $\delta^{18} \mathrm{O}, \mathrm{Na}+$, and $U$ in the sub-annually resolved portion of the record (1700-1998 CE), while the period between 1000-1699 CE was dated using an ice flow model constrained by the annually-counted top 300 years, and the identification of major historical volcanic eruptions from tephras preserved within the core. The maximum dating error is estimated to be \pm 0.5 years for the $20^{\text {th }}$ century, and $1-2 \%$ between 1000-1998 CE (Osterberg et al., 2008).

\section{Discussion}

\subsection{The link between dust and PP in the South Atlantic as recorded in the South Georgia Core}

Based on the hypothesised relationship between dust and PP (as shown conceptually in Fig. 1) it may be expected that there would be a relationship between dust flux and MSA concentrations in the SGC. As previously discussed, dust is not the only source of Fe (and other biologically important elements) in the HNLC ocean (Meskhidze et al., 2007). However, estimated soluble dust-Fe flux to the ocean surrounding South Georgia, at a mean input of $\sim 150 \mathrm{nmol} / \mathrm{m}^{2} /$ day (exceeding $1400 \mathrm{nmol} / \mathrm{m}^{2} /$ day during major dust events) is high in comparison to studies that measured atmospheric Fe flux in the vicinity of Kerguelen ( $2 \mathrm{nmol} / \mathrm{m}^{2} /$ day) (Chever et al., 2010; Wagener et al., 2008) and the Crozet Islands ( $100 \mathrm{nmol} / \mathrm{m}^{2} /$ day) (Planquette et al., 2007; Pollard et al., 2009). Soluble Fe flux was calculated as $10 \%$ of total iron flux for comparability (see Chever et al., 2010; Planquette et al., 2007). Additional factors such as light availability may also 
be a major control on oceanic PP either through seasonal limitation or the depth of the wind mixed layer (de Baar et al., 2005; Gabric et al., 2002; Pollard et al., 2009). In the case of South Georgia and particularly Mount Logan, PP in coastal waters may also contribute MSA to the study sites and this can be driven by elements derived from rivers, although dust deposition will also lead to phytoplankton blooms in coastal waters (Shaw et al., 2008).

A strong positive correlation was found between Fe and MSA ( $r=0.61, p<0.001, n=$ 70) within the top $6.48 \mathrm{~m}$ of the South Georgia Core (SGC), representing an approximately 20-month period of accumulation. The significant positive correlation between Fe and MSA concentrations in the SGC is suggestive of a link between dust-Fe deposition and PP in the SAO upwind of South Georgia. The high resolution of the SGC provides compelling evidence that PP, as measured by MSA deposition in the core, responds to event-scale dust-Fe input regularly. Phytoplankton population response time to iron deposition is on the order of 3-5 days (Boyd et al., 2007; Johnson et al., 2011), and it appears likely that these high frequency events are captured within the $\sim 10 \mathrm{~cm}$ sub-sections into which the core was divided for processing. Thus, peaks in Fe and MSA concentrations are assumed to represent events on the order of days or weeks. The SGC (Fig. 9) shows a number of defined dust-Fe deposition events that temporally match MSA deposition events. Interestingly these occur both in the austral summer and winter. It has been thought that light limitation was a major cause of reduced winter PP, and therefore resultant measured Chl concentrations, in the HNLC Southern Ocean (Gabric et al., 2002; Pollard et al., 2009). The high resolution of the SGC record however, appears to show that dust-Fe input may trigger PP response even in winter, although we note that overall PP is higher during the summer months.

In the SGC further evidence of wintertime dust-fertilisation of ocean waters is provided by individual dust transport events, which can be tracked using satellite imagery. Despite the limitations to the age model of the SGC, in at least one case, events have been identified within SGC. The most obvious event occurred on 16/08/2015 during which a dust plume is visible in MODIS imagery being emitted from the Patagonian coast at 1900 UTC (Fig. 11a). HYSPLIT forward trajectory modelling implies the dust transported in this event took approximately 24 hours to reach South Georgia (Fig. 11b). This is further confirmed by MODIS-Aqua Aerosol Optical Thickness (AOT) which captures the dust event moving away from the Patagonia coastline and across the South Atlantic, Southern Ocean, toward South Georgia on the 16/08/2015 and 17/08/2015 (Fig. 11c\&d). AOT data were filtered to only show values above 0.2 in order to ensure that low and background AOT values below 0.1 were excluded (Gassó et al., 2010; Ginoux et al., 2001). An increase in Chlorophyll a, as measured by MODISAqua/Terra satellite, is seen developing beneath the HYSPLIT forward trajectory modelled dust airmass pathway in the oceanic waters between Patagonia and South Georgia on 19/08/2015 and 21/08/2015 (Fig. 11e\&f). Chl a data were filtered to include only concentrations above $0.4 \mathrm{mg} / \mathrm{m}^{3}$, commensurate with peak average austral summertime values in the high latitude Southern Ocean (Song and Ke, 2015). It is assumed that this Chl event is associated with dust deposition from the 16-17/08/2015. The increase in $\mathrm{Chl}$ a occurs within the timeframe in which PP is expected to respond to dust fertilisation, that is approximately 3-4 days subsequent to the passage of the 
663 dust event (Boyd et al., 2007; Johnson et al., 2011). This dust event appears to have 664 been recorded in the SGC, where it likely represents the largest Fe and MSA spike visible 665 in the SGC record at 1.14 m depth (Fig. 9).

666
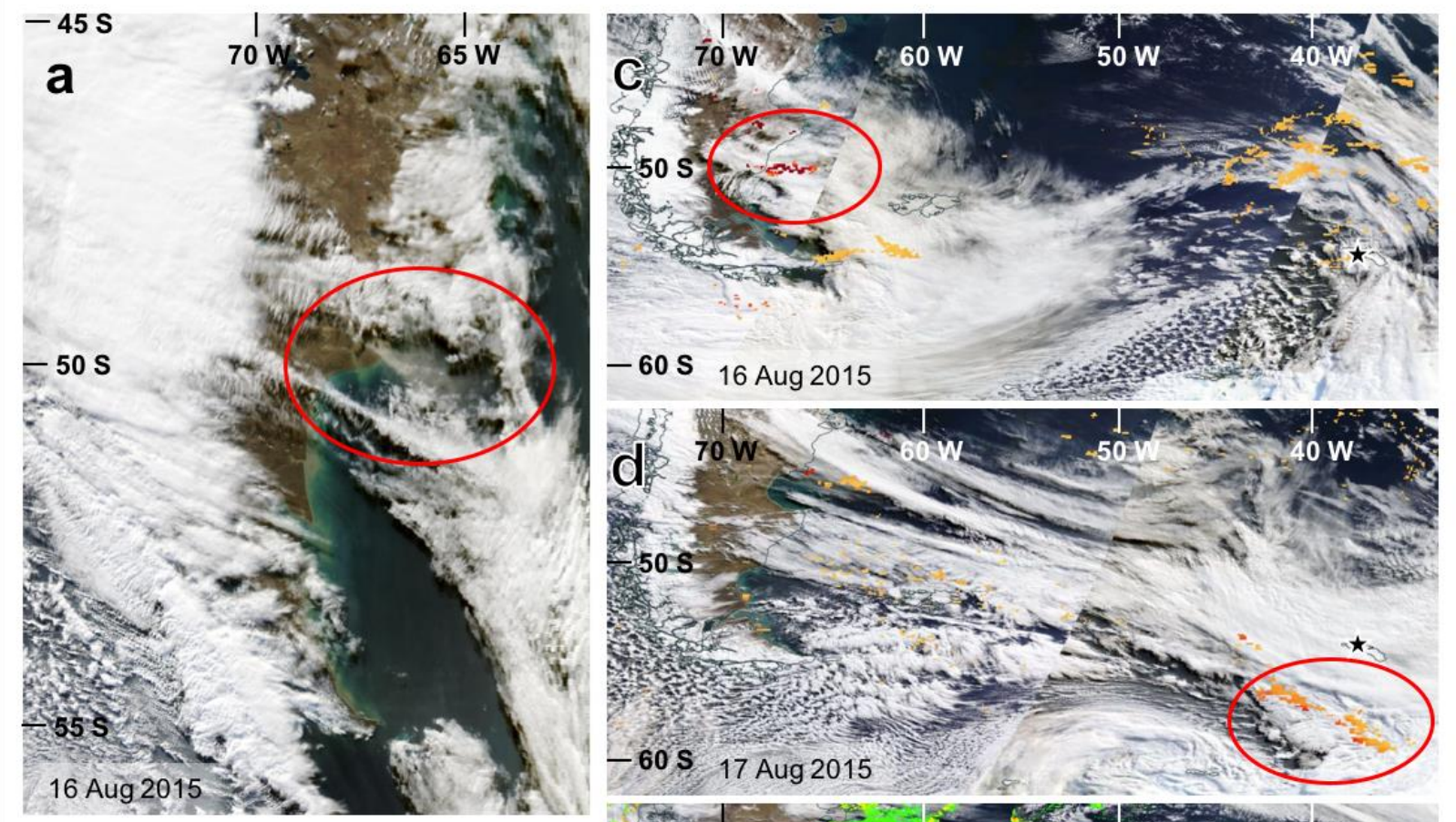

b

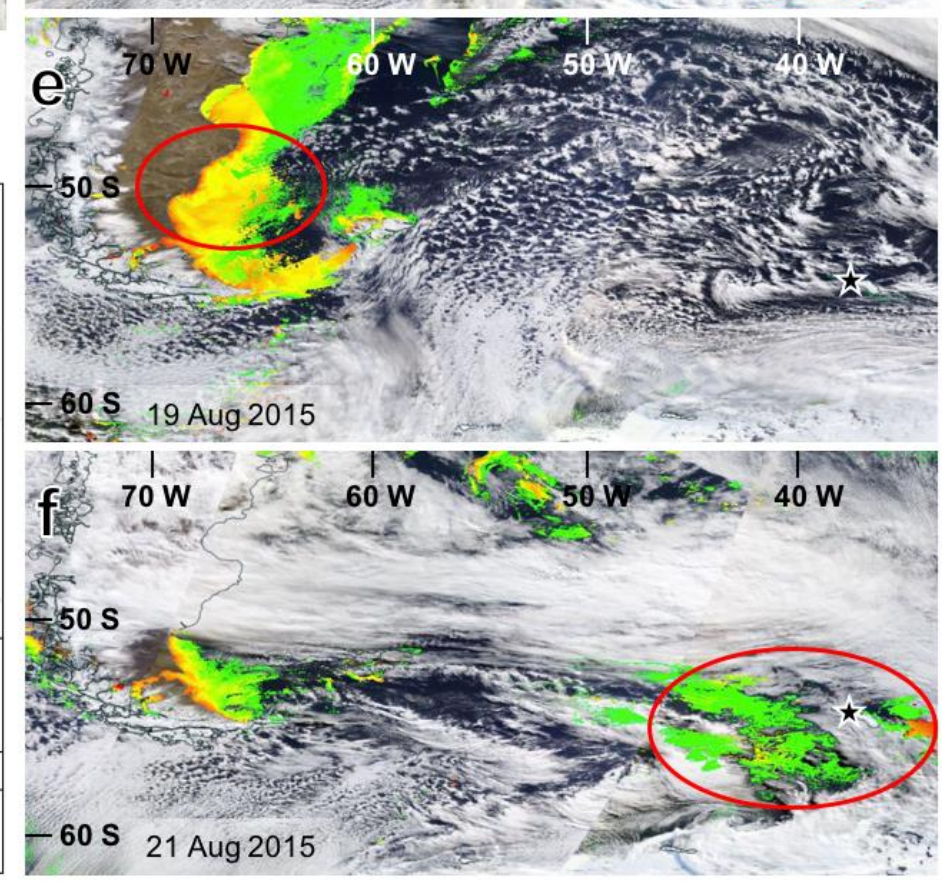

667

668

669

670

671

672

673

674

675

NOAA HYSPLIT MODEL

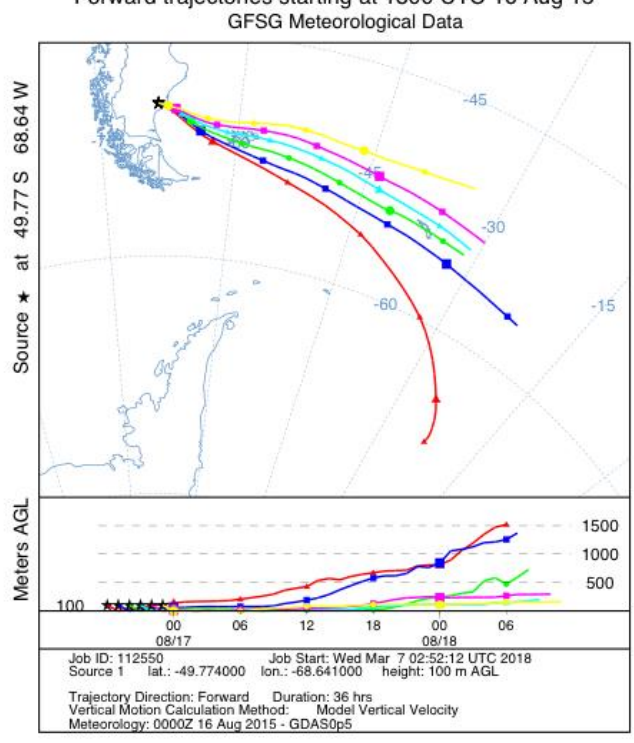

UTC 16 Aug 15 GFSG Meteorological Data

Figure 11. Tracking a Patagonian dust event and Potential Primary Productivity response in August 2015. (a) Satellite image (MODIS-Aqua) taken at 1900 UTC on $16^{\text {th }}$ August 2015 showing a large dust plume originating from the lower Rio Chico in Santa Cruz Province, Argentina. (b) HYSPLIT forward air mass trajectories from the dust source location beginning hourly between $1800-2300$ UTC on $16^{\text {th }}$ August 2015. Forward trajectories were run for 36 hours and record the dust plume's air mass passing close to and over South Georgia around 24 hours after emission. Earlier airmass trajectories take a more southerly route and subsequent airmass trajectories shift northwards and travel 
at lower altitudes over the SAO and SGC. Panels (c) and (d) show Merged Dark Target / Deep Blue AOT (MODIS-Aqua) values above a threshold of 0.2 to exclude background detection. (c) The dust plume is emitted from the lower Rio Chico over the SAO (activity highlighted by red circle) on the $16^{\text {th }}$ August 2015, and (d) is detected passing close to South Georgia and the SGC (black star) on the 17th August 2015, roughly 24 hours after emission. Panels (e) and (f) show $1 \mathrm{~km}$ resolution Chlorophyll a concentrations (MODISAqua/Terra) above a threshold of $0.4 \mathrm{mg} / \mathrm{m}^{3}$ to exclude background detection. Elevated Chl a concentrations are detected beneath the path of the dust plume (e) near the coast of Patagonia on the 19th August 2015, 3 days after the dust plume, and (f) close to South Georgia on the $21^{\text {st }}$ August 2015, 4 days after the dust event's air mass passed over the area.

Although the temporal resolution of the SGC is insufficient to unequivocally identify the timing of this Fe and MSA spike, based on the age-model for the core, the spike is most likely to occur in August, broadly coincident with the timing of the dust plume. It is also noteworthy that no other dust plumes of this scale were identified in satellite imagery between June - September 2015. We note however that overall the winter dust-PP response is based on few events, and therefore additional research is required to substantiate the importance of wintertime dust fertilisation events.

As well as $\mathrm{Fe}$, which is a major limiting element affecting oceanic PP, other biologically essential elements may also limit PP in the South Atlantic (Moore et al., 2013). Of the biologically important elements analysed within this study (Li, $\mathrm{Na}, \mathrm{Mg}, \mathrm{S}, \mathrm{K}, \mathrm{Ca}, \mathrm{V}, \mathrm{Cr}$, $\mathrm{Mn}, \mathrm{Fe}, \mathrm{Co}, \mathrm{Cu}, \mathrm{Zn}, \mathrm{Sr}, \mathrm{Cd}$ ), only Co concentrations were found to correlate more strongly with MSA than Fe in the SGC record $(r=0.67, p<0.001, n=70)$. Cobalt has been found to be a key secondary limiting element by a number of studies examining the influence of nutrients on oceanic PP, affecting phytoplankton growth through vitamin B12 availability (Dulaquais et al., 2017). Typically, Co is found to be limiting in situations where $\mathrm{Fe}$ is the major limiting element (Martin et al., 1989; Moore et al., 2013; Saito et al., 2005). This implies that Co may also be a key element limiting PP in the South Atlantic/Southern Ocean downwind of Patagonia.

\subsection{The link between dust and PP in the North Pacific as recorded in the Mount Logan core}

Like the SGC, annual concentrations of Fe and MSA in the MLC also show a significant positive correlation ( $r=0.38, p<0.001, n=982)$, and, as expected, this relationship is stronger when smoothed by a 5-year moving average $(r=0.5, p<0.001, n=974)$. Overall, however, the correlation between Fe and MSA in the MLC is weaker than in the SGC. This suggests the relationship between dust-Fe and MSA may be complex at Mount Logan.

The complexity of the relationship between dust and PP in the MLC is further demonstrated by changes to the dust-Fe/MSA relationship through time. Regime shift detection indicated an increase in average Fe deposition after 1874 CE by 69 \% (i.e., from 3.53 to $5.97 \mu \mathrm{g} / \mathrm{L}$ ). After the $1874 \mathrm{CE}$ shift detected in Fe deposition, average MSA 
concentrations are $41 \%$ higher (shifting from 1.16 to $1.64 \mu \mathrm{g} / \mathrm{L}$ ) than in the rest of the record preceding this point. However, whereas the increase in Fe from the 1870s CE is unprecedented in the MLC record, periods of higher or similar MSA concentrations occur in older parts of the core (Fig. 8), most notably between 1404-1619 CE. However, we note that the earlier period ( $1404-1619$ CE) of elevated MSA appears to be heavily affected by a single event. Despite the more complex history of regime shifts in the MSA data, the increase in dust deposition starting in the $19^{\text {th }}$ Century captured at Mt. Logan may have led to increased PP in the NPO during this period as evidenced by increasing MSA. Interestingly, however, the significant correlation in annual Fe and MSA concentrations in the ice $(r=0.43, p<0.001)$ between 1000-1873 CE, weakens in the period from 1874-1998 CE ( $r=0.15, p>0.05)$. This is despite the statistically significant increases in both the concentrations of both Fe and MSA during the latter period. The physical mechanisms that would explain a sustained increase in concentrations of both Fe and MSA and yet result in a reduction in the correlation between the two remain unclear. We note, however, that the timing of these regime shifts broadly coincide with the end of the Little Ice Age, which may have resulted in changes in atmospheric and ocean circulation patterns, aeolian transport pathways, sea ice duration and extent, and the location of HNLC regions, all of which have the potential to have impacted the effectiveness of dust fertilisation. Alternatively, intensified human activity and land disturbance in Asia and North America since the late $19^{\text {th }}$ Century may have resulted in a change in the composition and location of dust sources, which may have affected dust fertilisation (Hooper and Marx, 2018). For example, changing dust sources could result in dust being supplied to the MLC site without influencing Fe-limited oceanic waters (e.g. from novel dust sources in northeast China or even North America influencing the coring site; see Hooper and Marx, 2018).

To test the possibility that changes in ocean conditions may have influenced the relationship between dust and PP in the North Pacific, Fe and MSA concentrations in the MLC were compared with proxy data of oceanic variability over the past 1000 years using Pearson's r. This included Gulf of Alaska (GoA) temperature reconstructed from tree ring data (Wilson et al., 2007), and teleconnections influencing the North Pacific Ocean, namely the Pacific Decadal Oscillation (PDO) and the North Pacific Index (NPI). The Pacific Decadal Oscillation describes variability in SST in the central and western Pacific over the bi-decadal and penta-decadal time scales (see McGowan et al., 2009) and through its influence on climate and ocean conditions may influence both dust emissions (e.g. Lamb et al., 2009) and PP over these time scales. Two datasets of the PDO were used in the correlations, the reconstructed PDO record based on sea level pressure data from 1900 to 1998 CE (Mantua et al., 1997; Mantua and Hare, 2002) and from 1565 to 1998 CE from tree-ring reconstructions (D'Arrigo and Wilson, 2006). Similarly the NPI, a north to south variation in sea level pressure, linked to the position of the Aelutian Low in the northern Pacific (D'Arrigo and Wilson, 2006), also has the potential to influence dust output and PP. The operation of the NPI between 19001998 CE has been reconstructed using Na deposition in the MLC to create a proxy record for the Aleutian Low, and a reconstructed Dec - Mar North Pacific Index (NPI) (Osterberg et al., 2014). The resulting correlation coefficients were either absent or statistically insignificant in all cases (Table 1). There was no correlation between Fe or 
MSA concentrations with GoA surface air temperature, which is indicative of the strength of the Aleutian Low (Wilson et al., 2007). Similarly there were no significant correlations with either of the PDO records tested. The lack of correlation between either Fe and MSA and the NPI may reflect the fact that Asian dust transport and NPO PP would be expected to be most active during the Northern Hemisphere spring and summer (Duce, 1980; Hayes et al., 2013), whereas the MLC NPI was reconstructed from $\mathrm{Na}+$ concentrations likely linked to high wind speeds resulting from the development of a deep Aleutian Low during the wintertime (Osterberg et al., 2014). Consequently, there are no clear connections between Fe and MSA and ocean variability in the MLC record.

\begin{tabular}{|c|c|c|c|c|c|}
\hline \multirow[t]{2}{*}{ Record } & \multirow[t]{2}{*}{ Time Period (CE) } & \multicolumn{2}{|c|}{$\mathrm{Fe}$} & \multicolumn{2}{|c|}{ MSA } \\
\hline & & $r$ & $p$ & $r$ & $p$ \\
\hline Rec. Jan-Sep GOA Temp. ${ }^{a}$ & $1000-1998$ & 0.098 & $<0.01$ & 0.015 & $>0.05$ \\
\hline Inst. MAM PDO ${ }^{b}$ & 1900-1998 & -0.089 & $>0.05$ & 0.104 & $>0.05$ \\
\hline Rec. TR MAM PDO ${ }^{c}$ & 1565-1988 & -0.17 & $<0.01$ & -0.028 & $>0.05$ \\
\hline Rec. Logan DJFM NPI ${ }^{d}$ & 1900-1998 & -0.123 & $>0.05$ & 0.077 & $>0.05$ \\
\hline $\begin{array}{l}{ }^{a} \text { Gulf of Alaska Jan - Sep Tre } \\
{ }^{b} \text { Instrumental Spring (Mar- }- \\
\text { C Asian Tree-Ring (Mar-Apr- }- \\
{ }^{d} \text { Mount Logan Sodium (Na+ }\end{array}$ & $\begin{array}{l}\text { ng Temperature Re } \\
\text { May) Pacific Decada } \\
\text { Pacific Decadal Os } \\
\text { c - Mar North Pacif }\end{array}$ & $\begin{array}{l}\text { truction } \\
\text { illation In } \\
\text { on Index } \\
\text { ex Recor }\end{array}$ & $\begin{array}{l}\text { net al., } \\
\text { structio } \\
\text { ion (Ost }\end{array}$ & $\begin{array}{l}\text { rigo and } \\
\text { et al., } 2\end{array}$ & n, 2006) \\
\hline
\end{tabular}

Despite the lack of relationship between Fe, MSA and oceanic conditions, there does appear to be a relationship between dust and PP. Sediment cores from the North Pacific recording modern dust flux, show dust flux is high in the western Pacific, east of Hokkaido, Japan, and to a lesser extent east of the Kuril Islands and Kamchatka Peninsula, Russia. A second region of high dust flux occurs in the central North Pacific, south of the western Alaskan Peninsula (Serno et al., 2014). The emission of East Asian dust over the North Pacific is greatest during the Northern Hemisphere Spring (MarchApril-May (MAM)), and associated with the passage of cold fronts (Duce, 1980). Monthly average MAM atmospheric dust loads (Aerosol Optical Thickness (AOT) measured by MODIS Aqua satellite between 2003 and 2017) show high atmospheric dust loads extend into the central North Pacific east of Japan, particularly northeast of Hokkaido during these months (Fig. 12a), matching the core records of Serno et al. (2014). Similarly, MODIS Aqua satellite derived Chl observations for the same period show high Chl activity in this region is likely to be associated with dust fertilisation (Fig. 12b). Chl concentrations in the western NPO have been observed to more than double in response to dust events (Yoon et al., 2017). Importantly, however, there is also significant $\mathrm{Chl}$ production along the East Asian coast, in the Bering Sea and south of the 
Aleutian Islands which cannot be attributed to dust fertilisation. The impacts of this on the core results are discussed further in section 4.3.

The region to the east of Japan where PP appears most likely to be influenced by dustFe input is $>5000 \mathrm{~km}$ from the MLC site. Therefore MSA concentrations in the MLC are likely to be influenced by the paths of airmass trajectories that transport both dust (Osterberg et al., 2008) and MSA. Accordingly, the MLC site is unlikely to record a precise record of dust fertilisation events in the HNLC NPO, while in addition, there is also potential for dust and MSA associated with the same fertilisation event to be transported along different trajectories, i.e. dust may be transported to the coring site but associated MSA transported in a different direction by a secondary synoptic weather system. It is also noteworthy that higher concentrations of both Fe and MSA occur at the SGC site, despite its much higher snow accumulation rate (1.6 w.e. m/yr for SGC compared to 0.41 w.e. $\mathrm{m} / \mathrm{yr}$ for MLC), indicating the effect of the long-transport distances on diluting the dust and MSA signal at the Mount Logan site.

\subsection{Complexity in examining the dust-ocean fertilisation relationships using ice cores}

Despite correlations between MSA and dust-Fe being statistically significant for both the MLC and the SGC, a significant proportion of MSA concentrations in both cores is not explained by dust-Fe deposition, that is, the $r^{2}$ value is 0.37 and 0.15 in the SGC and MLC, respectively. Consequently, it is not possible to predict ocean PP based on dust deposition, i.e. dust-Fe input alone cannot explain the variance in MSA.

There are a number factors that could negatively influence the strength of the dust-Fe, MSA relationship in ice cores, i.e. lead to false negative results. This is because a positive correlation between dust-Fe and MSA response in ice requires a similar magnitude of dust and MSA deposition in close temporal proximity. Therefore, complexity in air-mass trajectories transporting dust and/or MSA, and depositional controls (e.g. rainfall scavenging), combined with the timing of DMS emission following dust fertilisation (typically lagging fertilisation by 2-10 days Levasseur et al., 2006; Turner et al., 1996), ocean precursor conditions i.e., light (Pollard et al., 2009; Venables et al., 2007), sea ice cover (Gabric et al., 2005), mixed layer depth (Evans et al., 2014) and phytoplankton species assemblage (Keller, 1989) all contribute to complexity in dust-Fe and MSA response as recorded in ice cores (see expanded discussion in Supplementary material).

Variable concentrations of Fe (and other biologically important elements) within dust source areas (e.g. Gaiero et al., 2004, 2003; Gili et al., 2017; Kamber et al., 2005; Marx et al., 2018; Marx and Kamber, 2010) are likely to further contribute to complexity in the dust-ocean fertilisation relationship. Dust is only one of a number of sources of Fe (and other nutrients) to the ocean. Other nutrient sources include fluvial input (Baek et al., 2009), hemipelagic sediment (Serno et al., 2014), including the advection of sediment from sub-ocean plateaus and island margins, as demonstrated at Kerguelen and Crozet Islands in the Southern Indian Ocean (Chever et al., 2010; Morris and Charette, 2013; Pollard et al., 2009), and ice rafted debris (Death et al., 2014). Volcanic eruptions are also an additional source of nutrients (Langmann, 2013; Olgun et al., 
2011). For example, a large bloom occurred in the NE Pacific ocean following the 2008 eruption of Kasatochi Volcano, Aleutian Islands (Hamme et al., 2010; Lindenthal et al., 2013). While major eruptions are easily accounted for in ice cores, the contribution of small or distal eruptions or even re-entrained ash is harder to ascertain. Therefore, PP and subsequent MSA production at either study site can be initiated by non-dust derived nutrients. In particular coastal waters tend to have high levels of PP (as shown for the NPO coast in Fig. 12b), as they are usually not nutrient-limited. However, despite the dominance of coastal Chl observable in Fig. 12b, the very large spatial area of the remote HNLC ocean implies the cumulative impact of low PP is very important.
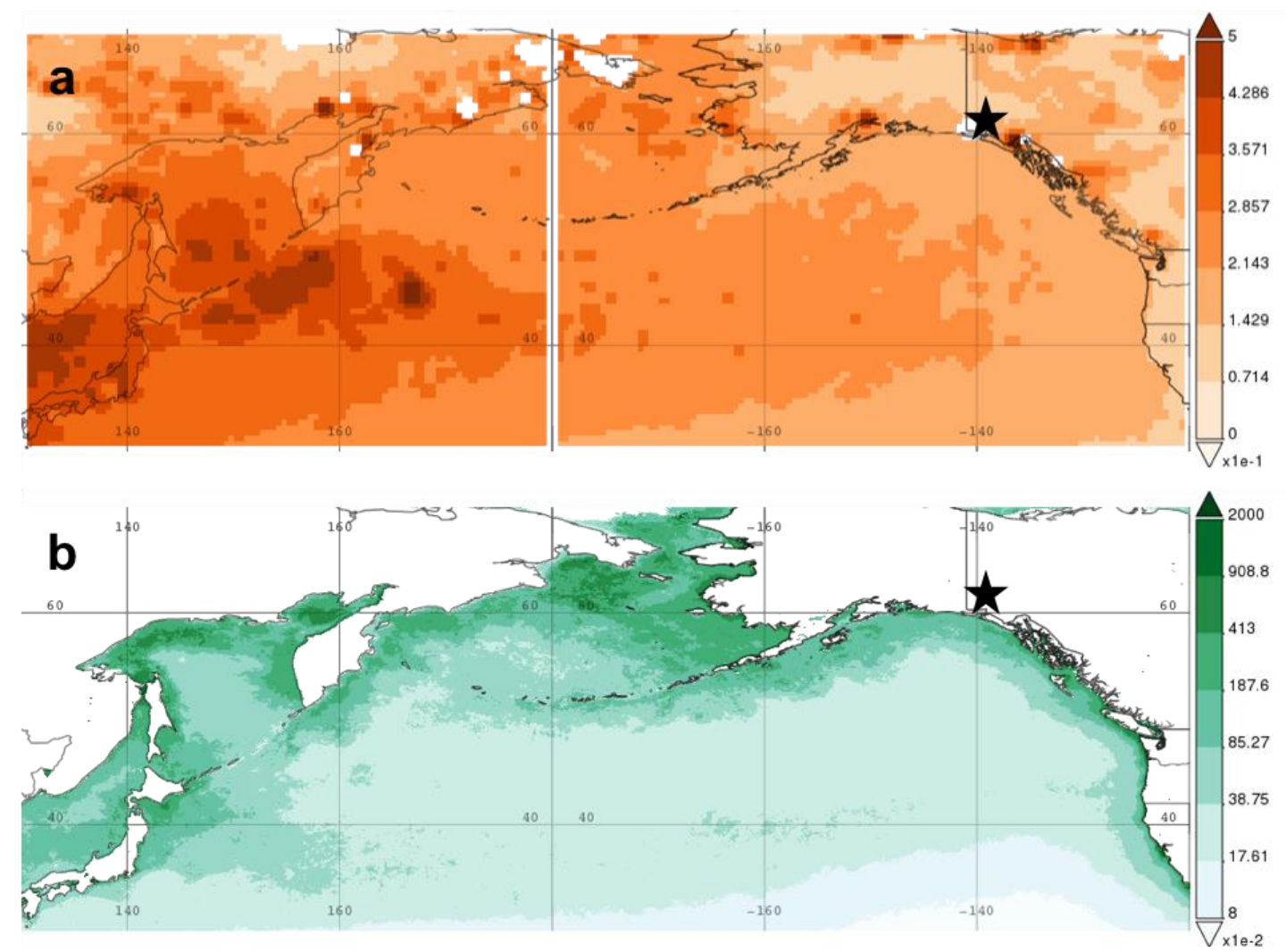

Figure 12. Springtime (MAM) spatial data for AOT and Chl in the North Pacific Ocean. (a) Dark target Aerosol Optical Thickness at 0.55 microns, scaled mean daily values averaged monthly at 1 degree resolution for MAM between 2003-2017 (MODIS-Aqua). (b) Chlorophyll a concentrations averaged monthly at $4 \mathrm{~km}$ resolution for MAM between 2003 - 2017 (MODIS-Aqua). The black star marks the location of the Mount Logan Core Site.

\section{Summary and Future Work}

This study has demonstrated a positive relationship existed between dust-Fe and MSA concentrations in ice cores from Mt Logan, reflecting Asian dust deposition and associated PP in the NPO, and South Georgia, reflecting Patagonian dust deposition and PP in the SAO. This relationship implies a priori that dust-Fe fertilisation makes a significant contribution to PP in both study regions. The relationship between dust-Fe and MSA deposition in the SGC was further verified by satellite imagery showing dust emissions from Patagonia, ocean $\mathrm{Chl}$ response and subsequent MSA and dust-Fe 
deposition in the core. However despite some examples, where satellite imagery can be used to track dust deposition and PP response in the high latitudes, persistent cloud cover and low winter light availability are major limitations to the application of satellite imagery for quantifying dust fertilisation in high latitude regions (Bullard et al., 2016; Gassó et al., 2010). For example, this is demonstrated in Figure 11, where despite dust and Chl being visible, the full extent of both the dust plume and the Chl response is obscured by cloud cover. Consequently, ice core data, as presented in this study, are a viable alternative for examining dust ocean fertilisation.

The addition of the ice core data from this study contributes to furthering understanding of the Fe hypothesis, by providing new continuous empirical datasets, which have positively identified a dust-Fe, MSA link across large spatio-temporal scales. The SGC indicates that aeolian input has the potential to drive DMS production on a continuous low-level event basis, evident through the strong correlation between Fe and MSA ( $r=0.61, p<0.001, n=70)$. These data suggest that while seasonal variables such as SST and light input create the conditions suitable for enhanced PP, aeolian Fe input is an important control of individual PP events. Accordingly, atmospheric Fe deposition may be a significant factor controlling phytoplankton productivity in the present-day SAO, to be considered alongside changes in winter mixing (Tagliabue et al., 2014) (annual scale) and ocean circulation (paleo timescales). This is in contrast to other event-scale studies that suggest upwelling and lateral advection as the primary source of Fe controlling biological activity (e.g. Chever et al., 2010; Meskhidze et al., 2007; Pollard et al., 2009). It is likely that aeolian deposition constitutes a greater share of Fe supply downwind of major continental dust sources, while in other areas more remote from dust transport corridors oceanic Fe sources are more important (Cassar et al., 2007). Additionally, the MLC record demonstrates the consistent nature of the correlation between aeolian Fe deposition and MSA on a multi-annual basis ( $r=0.5, p$ $<0.001, n=974$ ). However, the increase in dust flux in the MLC during the past 150 years, likely occurring in response to anthropogenic change within dust source areas (Hooper and Marx, 2018), resulted in a weakening of the correlation between MSA and dust deposition. Consequently, further work is needed to understand why this is the case. Taken together, however, the correlation between Fe and MSA concentrations in the ice cores present an intriguing hypothesis that, during the Holocene epoch at least, aeolian-derived Fe may play an important role in driving PP in both the SAO and NPO. This relationship is expected to have substantial impacts on associated ecosystem functions such as carbon export (Blain et al., 2007; Smetacek et al., 2012). As such, these preliminary results are an important first step in understanding further the relationship between dust, $\mathrm{PP}$ and atmospheric $\mathrm{CO}_{2}$ concentrations, both in the recent industrial past and in future climate scenarios.

The utility of ice cores to help understand the role of dust in iron-fertilisation of HNLC areas, as described in Figure 1 is not straightforward, particularly at an annual scale in the MLC, where the correlation between dust-Fe and MSA was weaker. This is potentially related to the long distances involved in transporting dust-Fe and associated DMS/MSA to the MLC, and to the greater complexity in the factors which influence PP over the larger spatial scale of the NPO. Thus the key limitations in using ice core records to investigate dust ocean fertilisation are 1 ) the positioning and proximity of a 
core site in relation to dust sources and HNLC ocean regions, 2) the presence of other non-dust Fe sources and areas of DMS production, 3) the frequency and consistency of airmass trajectories between dust and DMS sources and the core site and 4) variability in DMS production and phytoplankton growth. Correspondingly, the MLC, which is remote from its major East Asian dust sources, has a greater variety of Fe inputs and PP hotspots in the NPO, as well as more variable airmass trajectories, and records a weaker dust-MSA relationship than the SGC.

Future work is required to better understand the relationship between dust and PP over both event and paleo timescales. In the latter case, ice cores are one of a few environments offering high resolution records of dust and PP (via MSA response) over multi-millennial time frames. In addition to using ice cores, real time sampling combined with remote sensing offers significant potential for more fully understanding the dust/PP relationship. Although satellite data offer only relatively short term observations (e.g. 30 years) and, as previously noted, are often compromised by low light and frequent cloud cover at high latitudes, i.e. where the major HNLC oceanic regions are located, it nevertheless offers significant potential when used in combination with ice core data. We therefore propose that the way forward in examining the dust-PP relationship may be best achieved using a staged approached, combining multiple techniques including, 1) real-time air sampling downwind of known dust sources and recipient HNLC waters, 2) use of contemporary remote sensing data to measure and track dust emission events and downwind PP response, and 3) collection of ice cores to validate preservation of these MSA and dust data and to investigate this relationship over longer time scales.

\section{Acknowledgements}

The expeditions to collect both Ice cores were organised and enabled by the Climate Change Institute $(\mathrm{CCl})$ at the University of Maine. Major lons and trace elements analyses were undertaken at the $\mathrm{CCl}$ facility. The Climate Change Institute kindly provided the core data for this paper. The Mt. Logan project was supported by a US National Science Foundation grant to P. Mayewski. For the South Georgia core we would like to thank Skip Novak for his generous logistical support and guiding on South Georgia and to the Pelagic Australis team who sailed us to SG (Dave Roberts, Tomas Geipel \& Lizzy Fitzsimmons), and to the Westwind Expedition team who sailed on Pelagic Australis and assisted in the ice core retrieval and island logistics (P. Mayewski, S. Novak, G. Casassa, M. Potocki, J. Hooper, J. Auger, T. Smallwood). We are also grateful to the Government of South Georgia and the South Sandwich Islands for granting permission to undertake fieldwork on South Georgia, and to the British Antarctic Survey for their hospitality at the King Edward Point Station and help with retrieving weather data for the station. We are grateful to NASA for Chl and PAR data, and NOAA for SST data used in analysing the South Georgia Core. We thank Sam Lin for statistical advice. J. Hooper would like to thank the Australian Institute of Nuclear Science and Engineering and the University of Wollongong for funding support. The data used in this paper can be accessed via the Climate Change Institute's ice core data 
repository: http://cci.um.maine.edu/icecoredata/ or by contacting the corresponding author.

\section{References}

Albani, S., Mahowald, N.M., Murphy, L.N., Raiswell, R., Moore, J.K., Anderson, R.F., McGee, D., Bradtmiller, L.I., Delmonte, B., Hesse, P.P., Mayewski, P.A., 2016. Paleodust variability since the Last Glacial Maximum and implications for iron inputs to the ocean. Geophys. Res. Lett. 43, 3944-3954. https://doi.org/10.1002/2016GL067911

Baek, S.H., Shimode, S., Kim, H., Han, M.-S., Kikuchi, T., 2009. Strong bottom - up effects on phytoplankton community caused by a rainfall during spring and summer in Sagami Bay , Japan. J. Mar. Syst. 75, 253-264. https://doi.org/10.1016/j.jmarsys.2008.10.005

Bjørnstad, O.N., Falck, W., 2001. Nonparametric spatial covariance functions: Estimation and testing. Environ. Ecol. Stat. 8, 53-70. https://doi.org/10.1023/A:1009601932481

Blain, S., Queguiner, B., Armand, L.K., Belviso, S., Bomb, B., 2007. Effect of natural iron fertilization on carbon sequestration in the Southern Ocean. Nature 446, 1070-1074. https://doi.org/doi:10.1038/nature05700

Boyd, P.W., Jickells, T., Law, C.S., Blain, S., Boyle, E. a, Buesseler, K.O., Coale, K.H., Cullen, J.J., de Baar, H.J.W., Follows, M., Harvey, M., Lancelot, C., Levasseur, M., Owens, N.P.J., Pollard, R., Rivkin, R.B., Sarmiento, J., Schoemann, V., Smetacek, V., Takeda, S., Tsuda, a, Turner, S., Watson, a J., 2007. Mesoscale iron enrichment experiments 1993-2005: synthesis and future directions. Science 315, 612-617. https://doi.org/10.1126/science.1131669

Boyd, P.W., Mackie, D.S., Hunter, K.A., 2010. Aerosol iron deposition to the surface ocean - Modes of iron supply and biological responses. Mar. Chem. 120, 128143. https://doi.org/10.1016/j.marchem.2009.01.008

Bristow, C.S., Hudson-Edwards, K.A., Chappell, A., 2010. Fertilizing the Amazon and equatorial Atlantic with West African dust. Geophys. Res. Lett. 37, 3-7. https://doi.org/10.1029/2010GL043486

Bullard, J.E., Baddock, M., Bradwell, T., Crusius, J., Darlington, E., Gaiero, D., Gasso, S., Gisladottir, G., Hodgkins, R., McCulloch, R., 2016. High-latitude dust in the Earth system. Rev. Geophys. 54, 447-485. https://doi.org/10.1002/2016RG000518. Received

Cassar, N., Bender, M.L., Barnett, B. a, Fan, S., Moxim, W.J., li, H.L., Tilbrook, B., 2007. The Southern Ocean Biological Response to Aeolian Iron Deposition. Science (80-. ). 317, 1067-1070. https://doi.org/10.1126/science.1150011

Charlson, R.J., Lovelock, J.E., Andreae, M.O., Warren, S.G., 1987. Oceanic phytoplankton, atmospheric sulphur, cloud albedo and climate. Nature 326, 655-661.

Chever, F., Sarthou, G., Bucciarelli, E., Blain, S., Bowie, A.R., 2010. An iron budget during the natural iron fertilisation experiment KEOPS (Kerguelen Islands, Southern Ocean). Biogeosciences 7, 455-468. https://doi.org/10.5194/bg-7$455-2010$

Crusius, J., Schroth, A.W., Gassó, S., Moy, C.M., Levy, R.C., Gatica, M., 2011. Glacial 
flour dust storms in the Gulf of Alaska: Hydrologic and meteorological controls and their importance as a source of bioavailable iron. Geophys. Res. Lett. 38, 15. https://doi.org/10.1029/2010GL046573

D'Arrigo, R., Wilson, R., 2006. On the Asian expression of the PDO. Int. J. Climatol. 26, 1607-1617. https://doi.org/10.1002/joc.1326

de Baar, H.J.W., Boyd, P.W., Coale, K.H., Landry, M.R., Tsuda, A., Assmy, P., Bakker, D.C.E., Bozec, Y., Barber, R.T., Brzezinski, M.A., Buesseler, K.O., Boyé, M., Croot, P.L., Gervais, F., Gorbunov, M.Y., Harrison, P.J., Hiscock, W.T., Laan, P., Lancelot, C., Law, C.S., Levasseur, M., Marchetti, A., Millero, F.J., Nishioka, J., Nojiri, Y., van Oijen, T., Riebesell, U., Rijkenberg, M.J.A., Saito, H., Takeda, S., Timmermans, K.R., Veldhuis, M.J.W., Waite, A.M., Wong, C.S., 2005. Synthesis of iron fertilization experiments: From the iron age in the age of enlightenment. J. Geophys. Res. C Ocean. 110, 1-24. https://doi.org/10.1029/2004JC002601 Death, R., Wadham, J.L., Moneiro, F., Le Brocq, A.M., Tranter, M., Ridgwell, A., Dutkiewicz, S., Raiswell, R., 2014. Antarctic ice sheet fertilises the Southern Ocean. Biogeosciences 11, 2635-2644. https://doi.org/10.5194/bg-11-26352014

Duce, R.A., 1980. Long-Range Atmospheric Transport of Soil Dust from Asia to the Tropical North Pacific: Temporal Variability. Science (80-. ). 209, 1522-1525.

Dulaquais, G., Planquette, H., L'Helguen, S., Rijkenberg, M.J.A., Boye, M., 2017. The biogeochemistry of cobalt in the Mediterranean Sea. Global Biogeochem. Cycles 31, 377-399. https://doi.org/10.1002/2016GB005478

Evans, D.G., Zika, J.D., Naveira Garabato, A.C., Nurser, A.J.G., 2014. Oceans mass variability in Drake Passage 1-24. https://doi.org/10.1002/2014JC010097.Received

Falkowski, P., Scholes, R.J., Boyle, E., Canadell, J., Canfield, D., Elser, J., Gruber, N., Hibbard, K., Högberg, P., Linder, S., Mackenzie, F.T., Moore III, B., Pedersen, T., Rosenthal, Y., Seitzinger, S., Smetacek, V., Steffen, W., 2000. The Global Carbon Cycle: A Test of Our Knowledge of Earth as a System. Science 290, 291-296. https://doi.org/10.1126/science.290.5490.291

Gabric, A.J., Cropp, R., Ayers, G.P., McTainsh, G., Braddock, R., 2002. Coupling between cycles of phytoplankton biomass and aerosol optical depth as derived from SeaWiFS time series in the Subantarctic Southern Ocean - art. no. 1112. Geophys. Res. Lett. 29, NIL\{_\}433--NIL\{_\}436. https://doi.org/10.1029/2001GL013545

Gabric, A.J., Shephard, J.M., Knight, J.M., Jones, G., Trevena, A.J., 2005. Correlations between the satellite-derived seasonal cycles of phytoplankton biomass and aerosol optical depth in the Southern Ocean: Evidence for the influence of sea ice. Global Biogeochem. Cycles 19, 1-10. https://doi.org/10.1029/2005GB002546

Gaiero, D.M., Depetris, P.J., Probst, J.L., Bidart, S.M., Leleyter, L., 2004. The signature of river- and wind-borne materials exported from Patagonia to the southern latitudes: A view from REEs and implications for paleoclimatic interpretations. Earth Planet. Sci. Lett. 219, 357-376. https://doi.org/10.1016/S0012821X(03)00686-1

Gaiero, D.M., Probst, J.L., Depetris, P.J., Bidart, S.M., Leleyter, L., 2003. Iron and other transition metals in Patagonian riverborne and windborne materials: 
Geochemical control and transport to the southern South Atlantic Ocean. Geochim. Cosmochim. Acta 67, 3603-3623. https://doi.org/10.1016/S00167037(03)00211-4

Gassó, S., Stein, A., Marino, F., Castellano, E., Udisti, R., Ceratto, J., 2010. A combined observational and modeling approach to study modern dust transport from the Patagonia desert to East Antarctica. Atmos. Chem. Phys. 10, 8287-8303. https://doi.org/10.5194/acp-10-8287-2010

Gili, S., Gaiero, D.M., Goldstein, S.L., Chemale, F., Jweda, J., Kaplan, M.R., Becchio, R.A., Koester, E., 2017. Glacial/interglacial changes of Southern Hemisphere wind circulation from the geochemistry of South American dust. Earth Planet. Sci. Lett. 469, 98-109. https://doi.org/10.1016/j.epsl.2017.04.007

Ginoux, P., Chin, M., Tegen, I., Prospero, J.M., Holben, B., Dubovik, O., Lin, S.-J., 2001. Sources and distributions of dust aerosols simulated with the GOCART model. J. Geophys. Res. Atmos. 106, 20255-20273. https://doi.org/10.1029/2000JD000053

Ginoux, P., Prospero, J.M., Gill, T.E., Hsu, N.C., Zhao, M., 2012. Global-Scale Attribution of Anthropogenic and Natural Dust Sources and Their Emission Rates Based on Modis Deep Blue Aerosol Products 1-36. https://doi.org/10.1029/2012RG000388.1.INTRODUCTION

Hain, M.P., Sigman, D.M., Haug, G.H., 2010. Carbon dioxide effects of Antarctic stratification, North Atlantic Intermediate Water formation, and subantarctic nutrient drawdown during the last ice age: Diagnosis and synthesis in a geochemical box model. Global Biogeochem. Cycles 24, 1-19. https://doi.org/10.1029/2010GB003790

Hamme, R.C., Webley, P.W., Crawford, W.R., Whitney, F.A., Degrandpre, M.D., Emerson, S.R., Eriksen, C.C., Giesbrecht, K.E., Gower, J.F.R., Kavanaugh, M.T., Pea, M.A., Sabine, C.L., Batten, S.D., Coogan, L.A., Grundle, D.S., Lockwood, D., 2010. Volcanic ash fuels anomalous plankton bloom in subarctic northeast Pacific. Geophys. Res. Lett. 37, 1-5. https://doi.org/10.1029/2010GL044629 Hayes, C.T., Anderson, R.F., Fleisher, M.Q., Serno, S., Winckler, G., Gersonde, R., 2013. Quantifying lithogenic inputs to the North Pacific Ocean using the longlived thorium isotopes. Earth Planet. Sci. Lett. 383, 16-25. https://doi.org/10.1016/j.epsl.2013.09.025

Hooper, J., Marx, S., 2018. A global doubling of dust emissions during the Anthropocene? Glob. Planet. Change 169, 70-91. https://doi.org/10.1016/J.GLOPLACHA.2018.07.003

Ito, A., Shi, Z., 2016. Delivery of anthropogenic bioavailable iron from mineral dust and combustion aerosols to the ocean. Atmos. Chem. Phys. 16, 85-99. https://doi.org/10.5194/acp-16-85-2016

Jaccard, S.L., Hayes, C.T., Martínez-Garcia, A., Hodell, D. a, Anderson, R.F., Sigman, D.M., Haug, G.H., 2013. Two modes of change in Southern Ocean productivity over the past million years. Science 339, 1419-23. https://doi.org/10.1126/science.1227545

Jickells, T.D., An, Z.S., Andersen, K.K., Baker, A.R., Bergametti, G., Brooks, N., Cao, J.J., Boyd, P.W., Duce, R.A., Hunter, K.A., Kawahata, H., Kubilay, N., LaRoche, J., Liss, P.S., Mahowald, N., Prospero, J.M., Ridgwell, A.J., Tegen, I., Torres, R., 2005. Global Iron Connections Between Desert Dust, Ocean Biogeochemistry, and 
Johnson, M.S., Meskhidze, N., Kiliyanpilakkil, V.P., Gassó, S., 2011. Understanding the transport of Patagonian dust and its influence on marine biological activity in the South Atlantic Ocean. Atmos. Chem. Phys. 11, 2487-2502. https://doi.org/10.5194/acp-11-2487-2011

Johnson, M.S., Meskhidze, N., Solmon, F., Gassó, S., Chuang, P.Y., Gaiero, D.M., Yantosca, R.M., Wu, S., Wang, Y., Carouge, C., 2010. Modeling dust and soluble iron deposition to the South Atlantic Ocean. J. Geophys. Res. Atmos. 115, 1-14. https://doi.org/10.1029/2009JD013311

Kamber, B.S., Greig, A., Collerson, K.D., 2005. A new estimate for the composition of weathered young upper continental crust from alluvial sediments, Queensland, Australia. Geochim. Cosmochim. Acta 69, 1041-1058. https://doi.org/10.1016/j.gca.2004.08.020

Keller, M.D., 1989. Dimethyl Sulfide Production and Marine Phytoplankton : The Importance of Species Composition and Cell Size. Biol. Oceanogr. 6, 375-382. https://doi.org/https://doi.org/10.1080/01965581.1988.10749540

Knudson, K.P., Ravelo, A.C., 2015. Enhanced subarctic Pacific stratification and nutrient utilization during glacials over the last 1.2 Myr. Geophys. Res. Lett. 42, 9870-9879. https://doi.org/10.1002/2015GL066317

Kohfeld, K.E., Ridgwell, a. J., 2009. Glacial-interglacial variability in atmospheric $\mathrm{CO} 2$. Surf. Ocean - Low. Atmos. Process. 251-286. https://doi.org/10.1029/2008gm000845

Lamb, P.J., Leslie, L.M., Timmer, R.P., Speer, M.S., 2009. Multidecadal variability of eastern Australian dust and northern New Zealand sunshine: Associations with pacific climate system. J. Geophys. Res. Atmos. 114, 1-12. https://doi.org/10.1029/2008JD011184

Langmann, B., 2013. Volcanic Ash versus Mineral Dust: Atmospheric Processing and Environmental and Climate Impacts. ISRN Atmos. Sci. 2013, 1-17. https://doi.org/10.1155/2013/245076

Le Moigne, F.A.C., Moore, C.M., Sanders, R.J., Villa-Alfageme, M., Steigenberger, S., Achterberg, E.P., 2014. Sequestration efficiency in the iron-limited North Atlantic: Implications for iron supply mode to fertilized blooms. Geophys. Res. Lett. 41, 4619-4627. https://doi.org/10.1002/2014GL060308

Legrand, M., Feniet-Saigne, C., Saltzman, E.S., Germain, C., Barkov, N.I., Petrov, V.N., 1991. Ice-core record of oceanic emissions of dimethylsulphide during the last climate cycle. Nature 350, 144-146. https://doi.org/10.1038/350144a0

Levasseur, M., Scarratt, M.G., Michaud, S., Merzouk, A., Shing, C., Arychuk, M., Richardson, W., Rivkin, R.B., Hale, M., Wong, E., Marchetti, A., Kiyosawa, H., 2006. DMSP and DMS dynamics during a mesoscale iron fertilization experiment in the Northeast Pacific - Part I : Temporal and vertical distributions. Deep. Res. Part II Top. Stud. Oceanogr. 53, 2353-2369. https://doi.org/10.1016/j.dsr2.2006.05.023

Li, F., Ginoux, P., Ramaswamy, V., 2008. Distribution, transport, and deposition of mineral dust in the Southern Ocean and Antarctica: Contribution of major sources. J. Geophys. Res. Atmos. 113, 1-15. https://doi.org/10.1029/2007JD009190

Lindenthal, A., Langmann, B., Pätsch, J., Lorkowski, I., Hort, M., 2013. The ocean 
response to volcanic iron fertilisation after the eruption of Kasatochi volcano: A regional-scale biogeochemical ocean model study. Biogeosciences 10, 37153729. https://doi.org/10.5194/bg-10-3715-2013

Maher, B.A., Prospero, J.M., Mackie, D., Gaiero, D., Hesse, P.P., Balkanski, Y., 2010. Global connections between aeolian dust, climate and ocean biogeochemistry at the present day and at the last glacial maximum. Earth-Science Rev. 99, 6197. https://doi.org/10.1016/j.earscirev.2009.12.001

Mantua, N.J., Hare, S.R., 2002. The Pacific Decadal Oscillation. J. Oceanogr. https://doi.org/10.1023/A:1015820616384

Mantua, N.J., Hare, S.R., Zhang, Y., Wallace, J.M., Francis, R.C., 1997. Pacific interdecadal climate oscillation with impacts on salmon production. Am. Meteorol. Soc 78, 1069-1079. https://doi.org/10.1175/15200477(1997)078<1069:apicow>2.0.co;2

Martin, J.H., 1990. Glacial-interglacial CO 2 change: The Iron Hypothesis. Paleoceanography 5, 1-13. https://doi.org/10.1029/PA005i001p00001

Martin, J.H., Gordon, R.M., Fitzwater, S., Broenkow, W.W., 1989. Vertex: phytoplankton/iron studies in the Gulf of Alaska. Deep Sea Res. Part A, Oceanogr. Res. Pap. 36, 649-680. https://doi.org/10.1016/01980149(89)90144-1

Marx, S.K., Kamber, B.S., 2010. Trace-element systematics of sediments in the Murray-Darling Basin, Australia: Sediment provenance and palaeoclimate implications of fine scale chemical heterogeneity. Appl. Geochemistry 25, 12211237. https://doi.org/10.1016/j.apgeochem.2010.05.007

Marx, S.K., Kamber, B.S., McGowan, H.A., 2005. Provenance of long-travelled dust determined with ultra-trace-element composition: A pilot study with samples from New Zealand glaciers. Earth Surf. Process. Landforms 30, 699-716. https://doi.org/10.1002/esp.1169

Marx, S.K., Kamber, B.S., McGowan, H.A., Petherick, L.M., McTainsh, G.H., Stromsoe, N., Hooper, J.N., May, J.H., 2018. Palaeo-dust records: A window to understanding past environments. Glob. Planet. Change 165, 13-43. https://doi.org/10.1016/j.gloplacha.2018.03.001

Marx, S.K., McGowan, H.A., Kamber, B.S., 2009. Long-range dust transport from eastern Australia: A proxy for Holocene aridity and ENSO-type climate variability, Earth and Planetary Science Letters. Research Online. https://doi.org/10.1016/j.epsl.2009.03.013

McConnell, J.R., Aristarain, A.J., Banta, J.R., Edwards, P.R., Simões, J.C., 2007. 20thCentury doubling in dust archived in an Antarctic Peninsula ice core parallels climate change and desertification in South America. Proc. Natl. Acad. Sci. U. S. A. 104, 5743-5748. https://doi.org/10.1073/pnas.0607657104

McGowan, H.A., Marx, S.K., Denholm, J., Soderholm, J., Kamber, B.S., 2009. Reconstructing annual inflows to the headwater catchments of the Murray River, Australia, using the Pacific Decadal Oscillation. Geophys. Res. Lett. 36, 15. https://doi.org/10.1029/2008GL037049

McTainsh, G.H., 1989. Quaternary aeolian dust processes and sediments in the Australian region. Quat. Sci. Rev. 8, 235-253. https://doi.org/10.1016/02773791(89)90039-5

Meskhidze, N., Nenes, A., Chameides, W.L., Luo, C., Mahowald, N., 2007. Atlantic 
1204

1205

1206

1207

1208

1209

1210

1211

1212

1213

1214

1215

1216

1217

1218

1219

1220

1221

1222

1223

1224

1225

1226

1227

1228

1229

1230

1231

1232

1233

1234

1235

1236

1237

1238

1239

1240

1241

1242

1243

1244

1245

1246

1247

1248

1249

1250

Southern Ocean productivity: Fertilization from above or below? Global Biogeochem. Cycles 21, 1-9. https://doi.org/10.1029/2006GB002711

Moore, C.M., Mills, M.M., Arrigo, K.R., Berman-Frank, I., Bopp, L., Boyd, P.W., Galbraith, E.D., Geider, R.J., Guieu, C., Jaccard, S.L., Jickells, T.D., La Roche, J., Lenton, T.M., Mahowald, N.M., Maranon, E., Marinov, I., Moore, J.K., Nakatsuka, T., Oschlies, A., Saito, M.A., Thingstad, T.F., Tsuda, A., Ulloa, O., 2013. Processes and patterns of oceanic nutrient limitation. Nat. Geosci. 6, 701-710. https://doi.org/10.1038/ngeo1765

Moore, J.C., Grinsted, A., Kekonen, T., Pohjola, V., 2005. Separation of melting and environmental signals in an ice core with seasonal melt. Geophys. Res. Lett. 32, 1-4. https://doi.org/10.1029/2005GL023039

Morris, P.J., Charette, M.A., 2013. A synthesis of upper ocean carbon and dissolved iron budgets for Southern Ocean natural iron fertilisation studies. Deep. Res. Part II Top. Stud. Oceanogr. 90, 147-157. https://doi.org/10.1016/j.dsr2.2013.02.001

Muhs, D.R., 2018. The geochemistry of loess: Asian and North American deposits compared. J. Asian Earth Sci. 155, 81-115. https://doi.org/10.1016/j.jseaes.2017.10.032

Olgun, N., Duggen, S., Croot, P.L., Delmelle, P., Dietze, H., Schacht, U., Óskarsson, N., Siebe, C., Auer, A., Garbe-Schönberg, D., 2011. Surface ocean iron fertilization: The role of airborne volcanic ash from subduction zone and hot spot volcanoes and related iron fluxes into the Pacific Ocean. Global Biogeochem. Cycles 25, 115. https://doi.org/10.1029/2009GB003761

Osman, M., Das, S.B., Marchal, O., Evans, M.J., 2017. Methanesulfonic acid (MSA) migration in polar ice: Data synthesis and theory. Cryosphere 11, 2439-2462. https://doi.org/10.5194/tc-11-2439-2017

Osterberg, E.C., Mayewski, P., Kreutz, K., Fisher, D., Handley, M., Sneed, S., Zdanowicz, C., Zheng, J., Demuth, M., Waskiewicz, M., Bourgeois, J., 2008. Ice core record of rising lead pollution in the North Pacific atmosphere. Geophys. Res. Lett. 35, 1-4. https://doi.org/10.1029/2007GL032680

Osterberg, E.C., Mayewski, P.A., Fisher, D.A., Kreutz, K.J., Maasch, K.A., Sneed, S.B., Kelsey, E., 2014. Mount Logan ice core record of tropical and solar influences on Aleutian Low variability: 500-1998 A.D. J. Geophys. Res. 119, 11189-11204. https://doi.org/10.1002/2014JD021847

Owens, I., Zawar-Reza, P., 2015. Weather and Climate, in: Liggett, D., Storey, B., Cook, Y., Meduna, V. (Eds.), Exploring the Last Continent: An Introduction to Antarctica. Springer International Publishing, Cham, pp. 91-114. https://doi.org/10.1007/978-3-319-18947-5_6

Pabortsava, K., Lampitt, R.S., Benson, J., Crowe, C., McLachlan, R., Le Moigne, F.A.C., Mark Moore, C., Pebody, C., Provost, P., Rees, A.P., Tilstone, G.H., Woodward, E.M.S., 2017. Carbon sequestration in the deep Atlantic enhanced by Saharan dust. Nat. Geosci. 10, 189-194. https://doi.org/10.1038/ngeo2899

Planquette, H., Statham, P.J., Fones, G.R., Charette, M.A., Moore, C.M., Salter, I., Nédélec, F.H., Taylor, S.L., French, M., Baker, A.R., Mahowald, N., Jickells, T.D., 2007. Dissolved iron in the vicinity of the Crozet Islands, Southern Ocean. Deep. Res. Part II Top. Stud. Oceanogr. 54, 1999-2019. https://doi.org/10.1016/j.dsr2.2007.06.019 
1251

1252

1253

1254

1255

1256

1257

1258

1259

1260

1261

1262

1263

1264

1265

1266

1267

1268

1269

1270

1271

1272

1273

1274

1275

1276

1277

1278

1279

1280

1281

1282

1283

1284

1285

1286

1287

1288

1289

1290

1291

1292

1293

1294

1295

1296

1297

Polashenski, D.J., Osterberg, E.C., Koffman, B.G., Winski, D., Campbell, S., Lewis, G.M., 2018. Denali Ice Core Methanesulfonic Acid Records North Pacific Marine Primary Production. J. Geophys. Res. Atmos. 4642-4653. https://doi.org/10.1029/2017JD028123

Pollard, R.T., Salter, I., Sanders, R.J., Lucas, M.I., Moore, C.M., Mills, R. a, Statham, P.J., Allen, J.T., Baker, A.R., Bakker, D.C.E., Charette, M. a, Fielding, S., Fones, G.R., French, M., Hickman, A.E., Holland, R.J., Hughes, J.A., Jickells, T.D., Lampitt, R.S., Morris, P.J., Nédélec, F.H., Nielsdóttir, M., Planquette, H., Popova, E.E., Poulton, A.J., Read, J.F., Seeyave, S., Smith, T., Stinchcombe, M., Taylor, S., Thomalla, S., Venables, H.J., Williamson, R., Zubkov, M. V, 2009. Southern Ocean deep-water carbon export enhanced by natural iron fertilization. Nature 457, 577-580. https://doi.org/10.1038/nature07716

Prospero, J.M., Ginoux, P., Torres, O., Nicholson, S.E., Gill, T.E., 2002. Environmental characterization of global sources of atmospheric soil dust identified with the NIMBUS 7 Total Ozone Mapping Spectrometer (TOMS) absorbing aerosol product. Rev. Geophys. 40, 1-31. https://doi.org/10.1029/2000RG000095

Revel-Rolland, M., De Deckker, P., Delmonte, B., Hesse, P.P., Magee, J.W., BasileDoelsch, I., Grousset, F., Bosch, D., 2006. Eastern Australia: A possible source of dust in East Antarctica interglacial ice. Earth Planet. Sci. Lett. 249, 1-13. https://doi.org/10.1016/j.epsl.2006.06.028

Rodionov, S.N., 2004. A sequential algorithm for testing climate regime shifts. Geophys. Res. Lett. 31, 2-5. https://doi.org/10.1029/2004GL019448

Saito, M.A., Rocap, G., Moffett, J.W., 2005. Production of cobalt binding ligands in a Synechococcus feature at the Costa Rica upwelling dome. Limnol. Oceanogr. 50, 279-290. https://doi.org/10.4319/lo.2005.50.1.0279

Saltzman, E.S., Dioumaeva, I., Finley, B.D., 2006. Glacial/interglacial variations in methanesulfonate (MSA) in the Siple Dome ice core, West Antarctica. Geophys. Res. Lett. 33, 1-4. https://doi.org/10.1029/2005GL025629

Sañudo-Wilhelmy, S.A., Flegal, A.R., 2003. Potential influence of Saharan dust on the chemical composition of the Southern Ocean. Geochemistry, Geophys. Geosystems 4, 1-3. https://doi.org/10.1029/2003GC000507

Serno, S., Winckler, G., Anderson, R.F., Hayes, C.T., McGee, D., Machalett, B., Ren, H., Straub, S.M., Gersonde, R., Haug, G.H., 2014. Eolian dust input to the Subarctic North Pacific. Earth Planet. Sci. Lett. 387, 252-263. https://doi.org/10.1016/j.epsl.2013.11.008

Shaw, E.C., Gabric, A.J., McTainsh, G.H., 2008. Impacts of aeolian dust deposition on phytoplankton dynamics in Queensland coastal waters. Mar. Freshw. Res. 59, 951-962. https://doi.org/10.1071/MF08087

Smetacek, V., Klaas, C., Strass, V.H., Assmy, P., Montresor, M., Cisewski, B., Savoye, N., Webb, A., d'Ovidio, F., Arrieta, J.M., Bathmann, U., Bellerby, R., Berg, G.M., Croot, P., Gonzalez, S., Henjes, J., Herndl, G.J., Hoffmann, L.J., Leach, H., Losch, M., Mills, M.M., Neill, C., Peeken, I., Röttgers, R., Sachs, O., Sauter, E., Schmidt, M.M., Schwarz, J., Terbrüggen, A., Wolf-Gladrow, D., 2012. Deep carbon export from a Southern Ocean iron-fertilized diatom bloom. Nature 487, 313-319. https://doi.org/10.1038/nature11229

Song, C., ke, L., 2015. Bathymetrical influences on spatial and temporal characteristics of chlorophyll-a concentrations in the Southern Ocean from 
2002 to 2012 (October to March) using MODIS. Geo-Spatial Inf. Sci. 18, 200211. https://doi.org/10.1080/10095020.2015.1126934

Tagliabue, A., Sallée, J.-B., Bowie, A.R., Lévy, M., Swart, S., Boyd, P.W., 2014. Surfacewater iron supplies in the Southern Ocean sustained by deep winter mixing. Nat. Geosci. 7, 314-320. https://doi.org/10.1038/NGEO2101

Turner, S.M., Nightingale, P.D., Spokes, L.J., Liddicoat, M.I., Liss, P.S., 1996. Increased dimethyl sulphide concentrations in sea water from in situ iron enrichment. Nature 383, 513-517.

Uematsu, M., 2003. Atmospheric input of mineral dust to the western North Pacific region based on direct measurements and a regional chemical transport model. Geophys. Res. Lett. 30, 10-13. https://doi.org/10.1029/2002GL016645

Venables, H.J., Pollard, R.T., Popova, E.E., 2007. Physical conditions controlling the development of a regular phytoplankton bloom north of the Crozet Plateau, Southern Ocean. Deep. Res. Part II Top. Stud. Oceanogr. 54, 1949-1965. https://doi.org/10.1016/j.dsr2.2007.06.014

Wagener, T., Guieu, C., Losno, R., Bonnet, S., Mahowald, N., 2008. Revisiting atmospheric dust export to the Southern Hemisphere ocean: Biogeochemical implications. Global Biogeochem. Cycles 22, 1-13. https://doi.org/10.1029/2007GB002984

Wilson, R., Wiles, G., D'Arrigo, R., Zweck, C., 2007. Cycles and shifts: 1,300 years of multi-decadal temperature variability in the Gulf of Alaska. Clim. Dyn. 28, 425440. https://doi.org/10.1007/s00382-006-0194-9

Yoon, J., Kim, K., Macdonald, A.M., Park, K., Kim, H., Yoo, K., Yoon, H., Yang, E.J., Jung, J., Lim, J.-H., Kim, J.-H., Lee, J., Choi, T.-J., Song, J.-M., Kim, I.-N., 2017. Spatial and temporal variability of spring Asian dust events and their impacts on chlorophyll-a concentrations in the western North Pacific Ocean. Geophys. Res. Lett. 44, 1-9. https://doi.org/10.1002/2016GL072124

Yuan, W., Zhang, J., 2006. High correlations between Asian dust events and biological productivity in the western North Pacific. Geophys. Res. Lett. 33, 8-11. https://doi.org/10.1029/2005GL025174

Zdanowicz, C., Hall, G., Vaive, J., Amelin, Y., Percival, J., Girard, I., Biscaye, P., Bory, A., 2006. Asian dustfall in the St. Elias Mountains, Yukon, Canada. Geochim. Cosmochim. Acta 70, 3493-3507. https://doi.org/10.1016/j.gca.2006.05.005

Zorn, S.R., Drewnick, F., Schott, M., Hoffmann, T., Borrmann, S., 2008. Characterization of the South Atlantic marine boundary layer aerosol using an Aerodyne Aerosol Mass Spectrometer. Atmos. Chem. Phys. Discuss. 8, 48314876. https://doi.org/10.5194/acpd-8-4831-2008 